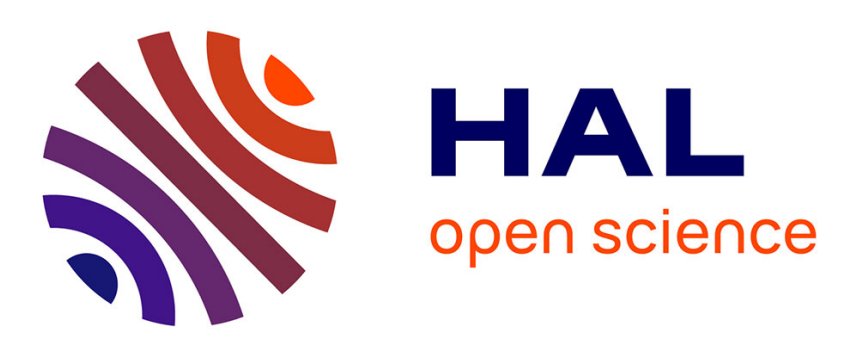

\title{
The Albian oceanic anoxic events record in central and northern Tunisia: Geochemical data and paleotectonic controls
}

\author{
Zina Khalifa, Hassene Affouri, Adel Rigane, Jérémy Jacob
}

\section{- To cite this version:}

Zina Khalifa, Hassene Affouri, Adel Rigane, Jérémy Jacob. The Albian oceanic anoxic events record in central and northern Tunisia: Geochemical data and paleotectonic controls. Marine and Petroleum Geology, 2018, 93, pp.145-165. 10.1016/j.marpetgeo.2018.03.016 . insu-01732530

HAL Id: insu-01732530

https://hal-insu.archives-ouvertes.fr/insu-01732530

Submitted on 14 Mar 2018

HAL is a multi-disciplinary open access archive for the deposit and dissemination of scientific research documents, whether they are published or not. The documents may come from teaching and research institutions in France or abroad, or from public or private research centers.
L'archive ouverte pluridisciplinaire HAL, est destinée au dépôt et à la diffusion de documents scientifiques de niveau recherche, publiés ou non, émanant des établissements d'enseignement et de recherche français ou étrangers, des laboratoires publics ou privés. 


\title{
The Albian Oceanic Anoxic Events record in Central and Northern Tunisia:
}

\section{Geochemical data and paleotectonic controls}

\author{
KHALIFA Zina ${ }^{1}$, AFFOURI Hassene ${ }^{1(*)}$, RIGANE Adel ${ }^{1}$, JACOB Jérémy ${ }^{2}$ \\ 1 Department of Earth Sciences, Research Laboratory GEOGLOB (Code LR13ES23)- \\ University of Sfax, Faculty of Sciences of Sfax, BP1171, 3000 Sfax, Tunisia. \\ ${ }^{2}$ Institute of Earth Sciences of Orleans (ISTO-UMR 7327, CNRS-University of Orleans, $1 \mathrm{~A}$ \\ rue de la Ferollerie, 45071 Orleans Cedex 2, France.
}

Emails:_klifazina@hotmail.fr_hassene_affouri@yahoo.fr,_riganeadel@yahoo.fr, jeremy.jacob@cnrs-orleans.fr

(*) Corresponding author

\begin{abstract}
The Albian organic-rich successions of the lower part of the Fahdene Formation (Albian to Cenomanian, Tunisia) were studied using sedimentology (analysis of carbonate contents and observation of thin sections), bulk organic geochemistry (Rock-Eval pyrolysis), and molecular biomarker distributions. The selected outcrops cover different structural domains from western central Tunisia (Jebel Hamra) to the Diapir zone or the Tunisian Trough (Koudiat Berkouchia, Jebel Ghazouan and Ain Asker from the southwest to the northeast, respectively).

Total Organic Carbon values between 0.17 and $3.43 \%$ evidenced the record of the Albian oceanic anoxic events OAE1b and OAE1c in this southern Tethys margin. Rock-Eval data and molecular biomarkers (n-alkanes, steranes and terpanes) revealed thermally mature organic matter (OM) consisting of a mixed Type II/III OM (marine planktonic and continental origins). The abundant tricyclic terpanes, C30 17 $\alpha(\mathrm{H})$ Diahopanes, and the regular decrease of homohopanes (C31 to $\mathrm{C} 35)$ in the terpane series, were also indicative of a high contribution of bacterial OM that had been developed under stagnant dysoxic/anoxic environments.
\end{abstract}


Microscopic thin section observations showed OM-rich micro-laminated mudstone to wackestone microfacies with abundant radiolarian and foraminifera. All of these features point to high surface primary organic productivity (POP) and the installation of an oxygen minimum zone (OMZ) at mid-depth of the Albian Basin. We suggest that the POP was the result of increased rich nutrient surface waters by upwelling and submarine volcanic activity. We integrated organic geochemical analysis with the structural context to explain both the variation in the OM richness and the record of these OAEs. The reactivation of faults limiting tilted blocks during the Aptian-Albian extension associated to the ascension of Triassic evaporites controlled the distribution and the preservation of organic-rich sequences from central-western to northern Tunisia. Therefore, we suggest that, as sea level rose during the Early Albian transgression, the structurally low areas invaded (grabens and inter-diapiric rim-synclines) represent very deep marine basins that lay beneath the OMZ limits. Therefore, the installation of an OMZ only coincided with half-graben structures that were either proximal and/or around the Triassic Diapir horsts. This could be the case of the Jebel Hamra and Koudiat Berkouchia localities during the Early Albian. We further propose that these localities may have recorded the OAE1b in the southern Tethys margin. Furthermore, the oscillations of this OMZ related to fluctuating POP and upwelling nutrient supplies, as well as the continental material supply by intensive weathering and seasonal rainfall, could explain both the facies alternations (marls/marly limestones) and the OM richness fluctuations along each studied section. The OAE1c recorded in the studied sections could result from the expansion of the OMZ all over the deep ramp platform, during the high stand sea level. Towards the extreme northeast part of this basin, the Ain Asker succession spanned the entire Albian stage, belonged to the deeper part of the Tunisian trough, probably below the OMZ limits, and therefore scarcely recorded these events.

Keywords: Albian, Organic matter, Oceanic Anoxic Events, Biomarkers, Tectonics, Tunisia. 


\section{Introduction}

The Albian age was characterized by an exceedingly warm climate, a small equator-topole temperature gradient, a lack of ice sheets, a high sea level, and significant tectonic and volcanic activity (Schlanger and Jenkyns, 1976; Jenkyns, 1980; Fenner, 2001; Leckie et al., 2002). Oceanic Anoxic Events (OAEs) occurred during the Albian and caused the expansion of extremely oxygen-poor waters in the oceans (Jenkyns, 2010). The most widely admitted causal factor was an expanded and intensified oxygen minimum zone (OMZ) of the ocean that enhanced the accumulation of marine organic-rich sediment (Jenkyns, 2010). Sea level rising and intense marine productivity are associated with OAEs (Erbacher et al., 1996). These episodic events resulted in the mass extinction of benthic fauna that was probably closely related to anoxia (oxygen-poor conditions) and oxidoreduction conditions of the water column in the ocean. Furthermore, black shales of the Early Albian Paquier event (OAE1b) in the Vocontian Basin (Bréhéret, 1985) are dominated by isoprenoid biomarkers of archaea as a major constituent of plankton (Kuypers et al., 2002; Tsikos et al., 2004). Black shales formed during OAEs are generally accompanied by an increase in radiolarian silica (Racki and Cordey, 2000; Jenkyns, 2003).

In central and northern Tunisia, the Albian to Cenomanian successions are represented by cyclic alternations of thinly laminated carbonates with marls and shales that form the Fahdene Formation (Burollet, 1956). Tectonically, the Early Jurassic rifting phase in the southern Tethyan margin (Northern-central Tunisia; Boughdiri et al., 2007) was characterized during this period by the reactivation of the NE-SW to E-W ante-Latest Albian deep-seated structural accidents associated with evaporite Diapir movements and local tilted blocks (Burollet and Ellouz, 1986; Martinez et al., 1991; Zouari et al., 1999). The resulting basin was filled by organic-rich deposits, in association with a sea level rise and hyper silicious conditions, features 
that typify the Tethys Realm during Albian-Cenomanian times (Racki and Cordey, 2000). During the Albian age, the structural context of Northern-central Tunisia was closely related to a general extensional regime that characterized the Tunisian margin. For example, at the Aptian-Albian transition, the tectonic regime was dominated by SW-NE extensive and/or transtensive deformation (Rigane et al., 2010). Thus, the sedimentation of the Fahdene Formation was interpreted to have been controlled by NE-SW, and E-W extensional horst and graben systems associated with synsedimentary normal faults (Rigane et al., 2010).

The reconstruction of the depositional environments by means of planktonic foraminifera (Chihaoui et al., 2010) suggests relatively deep-marine conditions corresponding probably to the outer part of a horst and graben ramp. Geochemical and biostratigraphic investigations showed that the general Albian OAE was recorded in the Albian pelagic sequences of northwestern Tunisia (Ben Fadhel et al. 2010), and can be correlated with time-equivalent series of Northern Tethyan margins. Ben Fadhel et al. (2010) also stated that the early Late Albian successions from Northwest Tunisia were characterized by intensive radiolarian productivity as evidenced by silica enrichment induced by hydrothermalism of halokinetic origin.

The present study combines sedimentological analysis (carbonate analysis and microfacies description of thin sections), Rock-Eval pyrolysis (organic matter richness, type and thermal maturity) and molecular biomarker records of samples recovered from the bottom of the Fahdene Formation. Four outcrop sections (Fig. 1) were selected recording different structural domains from: the "graben" zone (Jebel El Hamra: HM) North-west of Kasserine, the diapir zone (Koudiat Berkouchia: BRK and Jebel Ghazouane: GZ), and the Tunisian trough (Ain Asker: ASK). Our aims were to evaluate the paleogeographic and structural controls on Albian OM deposition and therefore the record of the oceanic anoxic events (OAE1b and/or 1c) in this southern Tethys margin.

\section{Stratigraphic and structural settings}


The Fahdene Formation (Albian-Cenomanian) was defined by Burollet in 1956 at the Oued Bahloul Anticline, Southeast of Makthar in central Tunisia. It consists of very thick series of marine sediments: gray to black marls and shales, with a few beds of limestones or marly limestones interbedded that overlie the limestone dominated Serdj Formation of Aptian age (Burollet, 1956; M'Rabet, 1981; Burollet et al., 1983; M'Rabet et al., 1995). Outside the type locality, the Fahdene Formation overlays the sandstone and clays of the Hameïma Formation (Late Gargasian-Early Clansayesian) in the localities of Slata, Hameïma, Boulahneche, and Djerissa (Zghal, 1994; Zghal et al., 1997; Chihaoui, 2009).

In its type locality (Fig. 1), the Fahdene Formation has been divided (Burollet, 1956) into five members: (1) The Lower Shale Member of Lower Albian age; (2) the Allam Limestone Member of Middle Albian age; (3) the Middle Shale Member of Late Albian age; (4) the Mouelha Limestone Member of Late Albian age and (5) the Upper Shale Member of latest Albian age. The stratigraphy of the Fahdene Formation was revised by Zghal (1994) and divided into only four members. Members 1, 2 and 3 of Zghal (1994) match members 1 to 3 of Burollet (1956), whereas members four and five of Burollet (1956) were grouped together into a fourth member (Zghal, 1994). Nonetheless, the problem of a global definition the AptianAlbian boundary remains a subject of disagreement (Casey et al., 1998; Kennedy et al., 2000; Hancock, 2001; Mutterlose et al., 2003). Many biostratigraphic studies conducted on the Serdj and Fahdene formations (Bismuth et al., 1981; El Euchi, 1993; Zghal et al., 1997; Memmi, 1999; Ben Haj Ali, 2005; Lehmann et al., 2009; Chihaoui et al., 2010; Ben Fadhel et al., 2014) have concluded that the Lower to Middle Albian pelagic successions are diachronic and affected by gaps. For example, El Euchi (1993) attributed the series between the Serdj Formation and the Lower shale Member of the Fahdene Formation, in Jebel Hamra, to the Late Aptian-lower Albian. 
The distribution of the Cretaceous sedimentary basins, in Tunisia, was controlled by major structural trends (Fig. 1). Northwest-Southeast and Northeast-Southwest trending faults controlled the position and initiation of the sedimentary basins that were cut by North-South and East-West trending transverse faults (Sainfeld 1951; Burollet, 1956; Burollet and Sainfeld, 1956; Chikhaoui, 1988; Chikhaoui et al., 2002). The reactivation of the main faults associated with these structural trends and the Triassic diapirism has resulted in a complex tectonic history. Consequently, the structural evolution of this region has been controlled by successive extensional and compressive tectonic events that also involved halokinesis (Perthuisot 1978; Ben Ayed 1986, 1994; Boukadi 1996; Perthuisot et al., 1998; Kadri and Ben Haj Ali, 1999; Chikhaoui et al., 2002).

The most important episode of Triassic evaporitic materials ascension (Fig. 1) took place during Aptian times (Snoke et al., 1988) and played an important role in the tectonosedimentary evolution of Tunisia (Boukadi et al., 1992). The horst and grabens created along extensional zones were disturbed by Triassic evaporitic deposits ascension that uplifted salt domes and tilted blocks. This configuration stimulated differential subsidence due to salt withdrawal until Cenomanian times in Central Tunisia (Soyer and Tricart, 1987). Accordingly, the Cretaceous basins in the "Tunisian Trough" matched the Triassic paleo-structures (Bismuth et al., 1982; Boltenhagen, 1985a, b; Bouaziz et al., 2002; Rigane et al., 2005).

The four Fahdene Formation outcrops sampled in this study were chosen from different paleogeographic and structural settings. The Koudiat Berkouchia (BRK) outcrop section belongs to the Mellegue "paleo-graben" (Chikhaoui et al., 1991), bordered by two structural highs: the Koumine to the West and the Nebeur to the East. This region is located at the SouthWestern extremity of the diapir zone (Perthuisot, 1978; Hatira et al., 2000). It is represented by complex tectonic structures related to the Triassic evaporitic deposits ascension movements and strike-slip faults (Chikhaoui et al., 1991, 2002; Chikhaoui and Turki, 1996; Memmi, 1999) (Fig 
1). According to these authors, the structural style complexity was the result of the extensive tectonic movement, which led to the extrusion of Triassic evaporites during the Aptian-Albian period. Consequently, movements of halokinetic and tilted blocks are responsible for the horst and graben structures (Chikhaoui et al., 1991). The Jebel Ghazouane outcrop section (GZ; Fig 1) is located about $26 \mathrm{~km}$ North-East from the BRK outcrop. Structurally, this locality belongs to the inter-diapiric zone where thick and complete series of marls were deposited in rimsynclines of the Teboursouk area between the diapirs of Jebel Thibar and Jebel Chehid (Fig. 1) (Perthuisot, 1978; Perthuisot, 1981; Hatira et al., 2000). The Ain Asker (ASK) outcrop section is located in the Northeast part of the Diapir zone (Fig. 1). It belongs to the Eastern part of the subsiding basin of the "Tunisian Trough" (Bolze et al., 1952; Jauzein, 1967; Burollet, 1973). The Jebel El Hamra (HM, Fig 1), an Aptian-Albian age outcrop series, is located in centralWestern Tunisia, Northwest of Kasserine and corresponds to the "graben zone". The Aptian recifal limestone outcrops are weathering resistant structures that dominate the relief in the Tajerouine area. The HM locality is bounded to the East by the NW transverse Graben of Kasserine and Foussana (GKF). The Kasserine region, in the central Tunisia platform (Martinez et al., 1991), is characterized by a major $\mathrm{N} 110^{\circ}$ trending fault on the edge of which the grabens of Kasserine and Foussana developed during the Miocene to Quaternary times (Philip et al., 1987). Many authors (Bismuth et al., 1981; Bismuth al., 1982; Bismuth et Mahjoub, 1985; Boltenhagen, 1985a, b; Batik et al. 1987) consider that the fault of Kasserine, like those of Gafsa (GF) to the South, and Kalaat Jerda-Sbiba (K.J-S.F.) to the North, was continually active, in particular during Albian-Aptian times and before the latest Albian transgression. According to Boltenhagen (1985a,b), at the end of the Aptian, the Kasserine Fault (K.F., Fig. 1) corresponded to the Southern limit of a large structural saddle basin. This structural style, which bends to the South, ensures the transition between the platform of central Tunisia and the "Tunisian Trough", as a stepped substratum with an elevated external ridge. Rigane et al. (2010) 
underlined, at Jebel Hamra, the prominent role of the paleo-structures acquired during the evolution of the South-Tethyan basin and their influence of the present-day geometry of the fold belt.

\section{Materials and methods}

Samples of the Fahdene Formation were recovered from four outcrop sections covering different structural domains in central and northern Tunisia (Fig. 1). From the bottom to the top of each outcrop section samples were selected from non-weathered black bituminous laminated marl and limestone levels.

\subsection{Samples}

The Fahdene Formation outcropping at BRK (Fig. 2) directly underlies the chaotic Triassic evaporites (gypsum). This formation is represented at the contact of these evaporites by greenish, glauconitic-rich clay. This succession is overlain by alternations of black coloured limestones and nodular marls and yellow to reddish limestone beds. Some limestone beds (e.g. BRK9) show bioturbation and syneresis cracks that represent the lower part of the "Allam Member" defined by Zghal et al. (1997) and Chihaoui et al. (2010).

The Fahdene Formation outcropping at GZ (Fig. 2) is represented by an alternation of limestone and marl levels. Above the Aptian dolostones, the ca. 200m thick clayey limestone and fissile green clays (samples GZ1 to GZ7) have been assigned to the Aptian-Albian age (Fakhraoui et al., 1998). This succession is overlain by alternations of grey marly limestones and limestones that have been attributed to the Latest Albian (samples GZ8 to GZ12) (Fakhraoui et al., 1998).

The Albian Fahdene Formation at HM (Fig. 2) consists of alternations of grey marls, marly limestone and limestone. These alternations have exposed ammonites, belemnite and rudists such as those from samples HM1 to HM17 and from HM24 to HM28. 
The sampled Fahdene Formation outcropping at the ASK cross-section (Fig. 2) is represented by ca. $500 \mathrm{~m}$ thick of regular alternations of grey marls and marly limestone intercalations and argillaceous limestone. This section covers probably all the Albian to the onset of the Cenomanian. The brown marls from samples ASK16 and ASK17 showed abundant pyrite concretion.

\subsection{Carbonate and Organic geochemical analysis}

Rock samples were powdered in an agate mortar. Powdered-dry samples were used for Rock-Eval pyrolysis, bitumen extraction and carbonate content analysis. Carbonate content expressed as $\mathrm{CaCO}_{3}(\%)$ was determined by using the Bernard Calcimeter method (Müller and Gastner, 1971; Vatan, 1967). Weighed samples were reacted with $3 \mathrm{~N} \mathrm{HCl}$. The volume of $\mathrm{CO}_{2}$ released, after reaction with $\mathrm{HCl}$, was measured and compared with the volume released from pure calcite. Thin sections from indurated limestone samples were prepared for optical microscopic observation and microfacies description.

Bulk organic geochemical parameters were determined using Rock-Eval pyrolysis under standard conditions with a Rock-Eval 6 apparatus (Vinci Technologies; Espitalié et al., 1985; Lafargue et al., 1998; Behar et al., 2001). The Rock-Eval pyrolysis method first consists in heating a small sample ( $100 \mathrm{mg})$ using a programmed temperature in a pyrolysis oven under an inert atmosphere (helium) to release the Pyrolysed Carbon (PC) as hydrocarbonaceous compounds, $\mathrm{CO}$ and $\mathrm{CO}_{2}$. Then, the residual sample is submitted to a second heating phase in a combustion oven, under oxidising conditions to release the Residual Carbon (RC) as CO and $\mathrm{CO}_{2}$. This method enables quantification of: (i) the free hydrocarbons pre-existing in the rock (S1; mg hydrocarbons (HC). $\mathrm{g}^{-1}$ rock), (ii) the hydrocarbons (S2; mg HC.g-1 rock) that are volatilized during the cracking of $\mathrm{OM}$ (kerogen) in the sample and represent the hydrocarbon generative potential, (iii) the $\mathrm{CO}_{2}$ and $\mathrm{CO}$ ( $\mathrm{S} 3$ as $\mathrm{mg}$ of $\mathrm{CO}$ and $\mathrm{CO}_{2 .} \mathrm{g}^{-1}$ rock) released during pyrolysis at temperatures $<390^{\circ} \mathrm{C}$, (iv) the temperature of maximum production of 
hydrocarbonaceous compounds during pyrolysis at the top of the S2 peak (Tmax), and (v) the Total Organic Carbon (TOC). The type and maturity of organic matter in petroleum source rocks can be characterized from Rock Eval pyrolysis data using the following parameters: (i) the hydrogen index (HI=S2x100/TOC, mg HC.g ${ }^{-1}$ TOC), (ii) the oxygen index (OI=S3x100/TOC, mg CO2. $\left.\mathrm{g}^{-1} \mathrm{TOC}\right)$, (iii) the production index $\left(\mathrm{PI}=\mathrm{S}_{1} /\left[\mathrm{S}_{1}+\mathrm{S}_{2}\right]\right)$. PI is used to characterize the evolution level of the organic matter.

The hydrocarbons were then extracted from powdered samples using an organic solvent $\left(\mathrm{CHCl}_{3}, 200 \mathrm{ml} / 30 \mathrm{~g}\right.$ sample). After vacuum filtration and solvent evaporation, we obtained the bitumen or the extractable organic matter (EOM) (Durand, 1993; Hunt, 1995). Then, the bitumen was fractionated using liquid chromatography with a single column packed with activated silica gel, into saturated hydrocarbons (SHC), aromatic hydrocarbons (AHC) and polar compounds (NSO). The column was eluted with hexane to obtain the SHC and with hexane/ $\mathrm{CHCl}_{3}(65: 35, \mathrm{v} / \mathrm{v})$ to obtain the AHC. The NSO fraction was retained at the top of the column. SHC were analysed using gas chromatography-mass spectrometry (GC-MS) to investigate the distribution of $n$-alkanes, acyclic isoprenoids (pristane and phytane) and cyclic alkanes (steranes and terpanes). GC-MS was performed with an HP 6890 series chromatograph equipped with a CPSIL 5CB fused silica column ( $25 \mathrm{~m} * 0.25 \mathrm{~mm}$ i.d.) connected to a Hewlett Packard 5973 mass selective detector (MSD) by a $2 \mathrm{~m}$ capillary interface at $250^{\circ} \mathrm{C}$. After splitless injection for 1 min., the oven temperature was increased from $100^{\circ} \mathrm{C}$ to $310^{\circ} \mathrm{C}$ at $3^{\circ} \mathrm{C}$ $\min ^{-1}$. The mass selective detector (MSD) was operated using the following conditions: $220^{\circ} \mathrm{C}$; electron energy $70 \mathrm{eV}$; scan range $\mathrm{m} / \mathrm{z}$ 50-450; $1 \mathrm{~s}$ per scan. The carrier gas was He. Peak height and relative intensities were measured from mass chromatograms of characteristic ions for alkanes (m/z 57), steranes ( $\mathrm{m} / \mathrm{z} 217)$ and terpanes (m/z 191).

\section{Results}

\subsection{Rock-Eval pyrolysis}


The Rock-Eval analysis results are reported in Table 1 and Figure 3. TOC values in the analysed samples varied widely in the range of 0.01 to $3.43 \%$. The highest TOC values registered were $3.43 \%, 2.90 \%$ and $1.32 \%$ in samples BRK5, GZ12 and HM30, respectively. The ASK samples showed a low OM content which did not exceed $0.89 \%$ of TOC. The free hydrocarbons S1 were very low ( $<0.9 \mathrm{mg} \mathrm{HC} / \mathrm{g}$ Rock) in all the samples analysed. The potential hydrocarbons S2 varied widely, along or between the outcrop sections. The samples BRK12, GZ12 and HM30 registered the highest values of 4.74, 2.79 and $2.3 \mathrm{mg} \mathrm{HC} . \mathrm{g}^{-1}$ Rock, respectively. As revealed from the OM contents, the ASK samples had very low S2 values $(<0.6$ mg HC. $\mathrm{g}^{-1}$ Rock). The wide range of variation of the S1 and S2 affected the PI. The PI values varied considerably, between 0.03 and 0.81 . The oxygen compounds $\mathrm{S} 3$ were very low $(<1 \mathrm{mg}$ $\mathrm{CO}_{2} \mathrm{~g}^{-1}$ Rock) in all the samples, but three samples (HM12, HM15 and ASK42) registered 2.13, 2.19 and $1.62 \mathrm{mg} \mathrm{CO}_{2} \mathrm{~g}^{-1}$ Rock, respectively.

The HI expresses the amount of hydrogen released from OM during pyrolysis. The HI values varied widely and ranged from 3 to $533 \mathrm{mg} \mathrm{HC} \cdot \mathrm{g}^{-1} \mathrm{TOC}$ (Table 1).The OI represents the oxygen released from the OM during pyrolysis. OI values also varied widely from very low (ca. $\mathrm{OI}<100 \mathrm{mg} \mathrm{CO} / \mathrm{g}$ TOC) to very high values (OI $>300 \mathrm{mg} \mathrm{CO} / \mathrm{g}$ TOC). HI and OI values can be used to determine the type of $\mathrm{OM}$ and its hydrocarbon proneness in a Pseudo-van Krevelen diagram (Tissot and Welte, 1984; Peters, 1986). Tmax values ranged from 439 to $453^{\circ} \mathrm{C}$.

\subsection{Carbonate and microfacies analysis}

The carbonate content varied widely through samples from ca. $1 \%$ to ca. $98 \%$ of $\mathrm{CaCO}_{3}$ (Table 1). These values are consistent with the field lithologies that consist of marls, marlcarbonates and carbonates. However, these values varied irregularly either in each outcrop or between the outcrop sections. Carbonate content in samples BRK varied between ca. 50 and $82 \%$ of $\mathrm{CaCO}_{3}$. The carbonate content of the $\mathrm{GZ}$ samples ranged from $0.93 \%$ to $89 \%$ of $\mathrm{CaCO}_{3}$. 
HM samples registered $\mathrm{CaCO}_{3}$ content ranging from $31 \%$ to $97 \%$. Finally, the ASK samples contained between 58 and $98 \%$ of $\mathrm{CaCO}_{3}$.

Thin section microscopic observations of representative indurated limestone beds samples from the BRK and GZ outcrops (Fig. 4) exhibited a cyclic alternation of fine dark (organic-rich) and light laminated wackestones (Folk, 1962; Dunham, 1962). These observations revealed abundant radiolarians, calcispheres and other bioclasts. Furthermore, microfractures (stylolites) were filled with brown coloured bitumen.

\subsection{Bitumen richness and composition}

Nine representative samples from the BRK (samples BRK11, BRK12 and BRK13), GZ (samples GZ8, GZ9 and GZ10) and HM (samples HM15, HM20 and HM30) outcrops were selected for biomarker analysis. The extractable organic matter (EOM) yield ranged from 0.12 to $1.86 \mathrm{mg} \mathrm{HC} . \mathrm{g}^{-1}$ rock (Table 2). These values represent ca. 0.5 to $19.2 \%$ of the TOC. The SHC in BRK, GZ and HM samples represented 13 to $76 \%$ of the EOM. Generally, the hydrocarbon fraction $(\mathrm{SHC}+\mathrm{AHC})$ predominated in the $\mathrm{EOM}$ of the $\mathrm{BRK}$ and $\mathrm{GZ}$ samples, whereas NSO compounds represented the majority (NSO>59\% EOM) of the EOM of the HM samples.

\subsection{The Fahdene Formation molecular signature}

\subsection{1. $n$-alkanes and acyclic isoprenoids}

The gas chromatography-mass spectrometry (GC-MS) analyses were carried out on the SHC fraction of representative samples from the HM, BRK and GZ cross-sections. The GCMS chromatograms (Total Ion Current: TIC) showed that most of the samples had $n$-alkane bimodal distributions maximizing in the $n-\mathrm{C}_{17}$ to the $n-\mathrm{C}_{20}$ and $n-\mathrm{C}_{24} / n-\mathrm{C}_{25}$ range ( ) with a regular decrease towards higher carbon numbers (Fig 4). Acyclic isoprenoids, especially norpristane $\left(i-\mathrm{C}_{16}\right)$, pristane $\left(\mathrm{Pr} ; i-\mathrm{C}_{19}\right)$ and phytane $\left(\mathrm{Ph} ; i-\mathrm{C}_{20}\right)$ were relatively abundant in the SHC fraction. Pristane/phytane $(\mathrm{Pr} / \mathrm{Ph}$, Table 2) ratio values varied between ca. 1 (sample HM30) to 
2.4 (sample BRK12). The $\mathrm{Pr} / n-\mathrm{C}_{17}$ ratio values (Table 2) varied from 0.57 to 1.13 , whereas the $\mathrm{Ph} / n-\mathrm{C}_{18}$ ratio values were very low and did not exceed 0.95 (Table 2). We tentatively identified squalane in high relative proportions in the BRK samples (Fig. 5).

\subsubsection{Hopanes and steranes}

The representative samples from each outcrop were analyzed by GC-MS for their tricyclic and pentacyclic triterpane $(\mathrm{m} / \mathrm{z}$ 191) and sterane $(\mathrm{m} / \mathrm{z}$ 217) distributions (Fig. 6). The tricyclic terpane series (Fig. 6; Table 2) extended from the C23 up to C26. The hopane series extended from the $\mathrm{C} 27$ to the $\mathrm{C} 35$ and were dominated by $17 \alpha(\mathrm{H}), 21 \beta(\mathrm{H})$ hopane [abbreviated $\mathrm{C} 30 \mathrm{H}$; $\alpha \beta \mathrm{C} 30 \mathrm{H}]$ and $17 \alpha(\mathrm{H}), 21 \beta(\mathrm{H})$ nor-hopane [abbreviated $\mathrm{C} 29 \mathrm{H} ; \alpha \beta \mathrm{C} 29 \mathrm{H}]$. None of the samples showed any $\beta \beta$ and $\beta \alpha$ hopanes (moretanes). All the samples had a high $\mathrm{C} 30 \mathrm{H} / \mathrm{C} 29 \mathrm{H}$ ratio (Table 4) ranging from 1.07 to 3.63 . The homohopane series decreased regularly from C31 to C35 in all samples (Fig 6). Furthermore, the m/z 191 chromatograms of the BRK12, GZ10, and HM30 samples (Fig. 6) showed high extended tricyclic terpanes from C19 to C29 (Ekweozor and Strausz, 1982), subordinate C24 tetracyclic terpanes, high $18 \alpha(\mathrm{H})$-trisnorneohopane (C27Ts) compared to $17 \alpha(\mathrm{H})$-trisnorhopane $(\mathrm{C} 27 \mathrm{Tm})$ and relatively abundant C29Ts. All the samples exhibited a high peak of the $\mathrm{C} 3017 \alpha(\mathrm{H})$-diahopane. As shown in Table 4 the Ts/Tm ratio ranged from 0.77 (sample HM3) to 3.39 (samples HM30), corresponding to Ts/Ts+Tm ratio values ranging from 0.43 to 0.77 . The $\mathrm{C} 29 \mathrm{Ts} / \mathrm{C} 29 \mathrm{H}$ ratio varied between 0.35 (samples HM3) and 1.93 (sample BRK12). All the samples but one (HM3) had a high (>1) C30 17 $\alpha(\mathrm{H})$ diahopane/C29H ratio ranging from to 0.47 to 1.46 and a relatively high Diahopane Index (DI $=\mathrm{C} 3017 \alpha(\mathrm{H})$-diahopane/ $(\mathrm{C} 3017 \alpha(\mathrm{H})$-diahopane $+\mathrm{C} 30 \mathrm{H})$ in the range 0.25-0.53 (Table 4).

The sterane (m/z 217) fingerprints of the representative samples from the HM, BRK, and GZ cross-sections are displayed in Fig 6. All the chromatograms show regular and rearranged steranes extending from $\mathrm{C} 27$ to $\mathrm{C} 30$ (Fig. 6; Table 3). Very low amounts of C30 steranes, much lower than those of the C27 to C29, occurred in all of the samples. The C27 
diasteranes were the prominent compounds in all samples compared to the regular C27 to C29 steranes (Fig. 6).

All samples contained small amounts of the $14 \alpha(\mathrm{H}), 17 \alpha(\mathrm{H})-20 \mathrm{RC} 28$ sterane $(\alpha \alpha 20 \mathrm{R}$ C28) compared to its $\mathrm{C} 27$ and $\mathrm{C} 29$ homologs. The $14 \alpha(\mathrm{H}), 17 \alpha(\mathrm{H})-20 \mathrm{RC} 27(\alpha \alpha 20 \mathrm{RC} 27)$ predominates in the regular sterane series (i.e. $\alpha \alpha 20 \mathrm{R} \mathrm{C} 27, \mathrm{C} 28$, and C29 regular steranes) (Fig. 6; Table 3). By contrast, the $14 \beta(\mathrm{H}), 17 \beta(\mathrm{H})-20 \mathrm{R}(\beta \beta 20 \mathrm{R})$ and $14 \beta(\mathrm{H}), 17 \beta(\mathrm{H})-20 \mathrm{~S}(\beta \beta 20 \mathrm{~S})$ isomers dominate over the $\alpha \alpha 20 \mathrm{R}$ and $20 \mathrm{~S}$ compounds for the $\mathrm{C} 29$ sterane. All samples show high ratios of the $29 \alpha \mathrm{S} / 29 \alpha(\mathrm{S}+\mathrm{R}), 29 \beta \mathrm{S} / 29 \beta(\mathrm{S}+\mathrm{R})$ and $29 \beta(\mathrm{S}+\mathrm{R}) /[(29 \beta(\mathrm{S}+\mathrm{R})+29 \alpha(\mathrm{S}+\mathrm{R})]$ ranging from $0.45-0.50,0.44-0.55$ and $0.45-0.62$, respectively (Table 4). The 27DS/27D(S+R) ratio vary from 0.59 to 0.68 .

\section{Discussion}

\subsection{The Albian OM sedimentation, richness, origin, and thermal maturity}

A source rock can be broadly defined as any fine-grained, organic-rich rock that is able to generate petroleum when it is sufficiently exposed to heat and pressure. Its petroleumgenerating potential is directly related to its $\mathrm{OM}$ richness and thermal maturity. TOC is an important parameter in the evaluation of petroleum source rocks. Tissot and Welte (1984) and Peters and Casa (1994) proposed a scale for the assessment of the petroleum potential of source rocks, based on TOC, S1 and S2 values. In our samples, the TOC, S1, S2, and S3 parameters varied widely between samples and outcrop localities (Table 1). These variations can be interpreted as dependent on the origin, the preservation and the paleo-environmental conditions in which sediments were deposited. The TOC values showed discrepancies either vertically across one outcrop section or regionally between outcrops. Therefore, the highest TOC values, which range between 0.5 and $3.43 \%$, were registered in the BRK and GZ localities. The TOC values were moderate and did not exceed $0.9 \%$ in the HM and ASK outcrops, to the South and to the North-East of the studied area, respectively. 
The carbonate content of the studied outcrops (Table 1) varied between ca. 1\% and 98\% of $\mathrm{CaCO}_{3}$. These highly variable values are in agreement with the observed rhythmic alternation of limestone, marls and marly limestone. The $\mathrm{CaCO}_{3}$ and $\mathrm{TOC}$ contents did not show a linear correlation in the studied sections. In order to identify the main factor of differences in the relative carbonate and organic matter content in these limestones and marls, we used a TOC-CaCO 3 diagram (Ricken, 1993). The location of the samples on this diagram (Fig. 7) agreed with a moderately bioturbed-dysaerobic deposition environment. Consequently, this variability in TOC contents could be explained by the effect of bioturbation on the sediments allowing their oxygenation and therefore the oxidation of OM.

The microscopic observations of representative limestone bed samples from the BRK and GZ outcrops (Fig. 3) exhibited a cyclic alternation of fine dark (organic-rich) and light laminated wackestone limestone (Folk, 1962; Dunham, 1962). Microscopic observation revealed that the wackestones are radiolarian rich; calcispheres and other bioclasts are also common components. Microfractures (stylolites) are filled with bitumen. These wackestones are indicative of an environment changing from dysoxic to anoxic conditions on the sea floor (Leckie et al., 2002).

The Fahdene Formation outcrops studied show an alternation of marls and limestone beds. These alternations are interpreted as orbitally-forced (Herbert and Fischer, 1986; Sageman et al., 1998; Fiet et al., 2001; Galeotti et al., 2003; Grippo et al., 2004; Tyszka, 2009). Ben Fadhel et al. (2011) grouped these alternations in a package of laminated, grey to black marl and black-coloured limestone beds, which lie within the Mid-Albian breggiensis planktonic foraminifer biozone. The black shale layers interbedded within these alternations bearing moderately abundant radiolarian, in the BRK outcrop section, span the entire uppermost part of the breggiensis biozone (Ben Fadhel et al., 2011). Arthur et al. (1990) and Bralower et al. (1993) pointed out that the OAE1c straddles the entire breggiensis biozone. In our present study and by lithologic correlation with the work of Ben Fadhel et al. (2011), the BRK samples 
cover this zone from the upper part of the Allam Member (middle Albian age) to the Mouelha Member (Latest Albian age) (Zghal et al., 1997). Elsewhere, at the HM, GZ and ASK outcrop sections, the sampled successions probably cover the Early to Late Albian. In our study, the part of the HM outcrop between samples HM1 to HM10 is attributed to the Late Aptian-lower Albian age (Burollet, 1956; El Euchi, 1993; Zghal, 1994; Chihaoui, 2009; Jaillard et al., 2013). In this outcrop section, this stratigraphic interval can be considered synonymous of the OAE1b. Accordingly, the organic-rich levels registered in the HM outcrop samples probably correspond to the Early and Late Albian, OAE1b and OAE1c, respectively (Arthur and Silva, 1982; Bréhéret et al., 1986; Silva et al., 1989; Bralower et al., 1993, 1999; Leckie et al., 2002; Wagner et al., 2008), whereas the organic rich samples of the BRK and GZ outcrops correlate with the Late Albian OAE1c (Pratt and King, 1986; Bralower et al., 1993; Coccioni and Galeotti, 1993; Haig and Lynch, 1993; Erbacher et al., 1996). In the ASK outcrop, which represents the deepest facies of the Albian successions, scarcely recorded these events.

$\mathrm{HI}$ and $\mathrm{OI}$ are directly related to the atomic hydrogen to carbon ratio $(\mathrm{H} / \mathrm{C})$ and oxygen to carbon ratio (O/C), respectively (Espitalié et al., 1985; Lafargue et al., 1998; Behar et al., 2001). Marine organisms and algae, in general, are composed of lipid and protein-rich organic matter with a higher $\mathrm{H} / \mathrm{C}$ than that of the carbohydrate-rich constituents of land plants. HI values typically range from $~ 100 \mathrm{mg} \mathrm{HC} . \mathrm{g}^{-1} \mathrm{TOC}$ to $600 \mathrm{mg} \mathrm{HC} \cdot \mathrm{g}^{-1} \mathrm{TOC}$ in geological samples. In our study, the HI and OI values (Table 1) showed that the OM in the Fahdene Formation is poorly hydrogenated $\left(\mathrm{HI}<300 \mathrm{mg} \mathrm{HC} . \mathrm{g}^{-1} \mathrm{TOC}\right)$ and very variably oxygenated. Only one sample from the GZ locality (GZ9) has preserved a good HI (533 mg HC.g ${ }^{-1}$ TOC). Obviously, the OI values of the ASK samples and some levels from the HM locality are much higher than those of the other localities (OI>100 mg CO $2 \mathrm{~g}^{-1}$ TOC). A modified Van Krevelen diagram that plots HI versus OI values (Fig. 8a) reveals that the organic matter preserved in this Formation varies from oil-prone (Type II) kerogen to oil and gas-prone (Type II/III) kerogen with a liquid and 
gaseous hydrocarbon production potential. Furthermore, this indicates a poorer residual generation potential of the OM and thus, a higher organic maturity. The higher organic maturity is supported by the Tmax values $\left(440^{\circ} \mathrm{C}<\mathrm{Tmax}<453^{\circ} \mathrm{C}\right.$, Table 1 , Fig. $\left.8 \mathrm{~b}\right)$ which suggest that the OM of the Fahdene Formation in the studied outcrops has reached the thermal maturity for hydrocarbon generation (oil window, Tissot and Welte, 1978; Durand, 1980; Bordenave, 1993; Vandenbroucke et al., 1993). Other evidence of oil production is the presence of bitumen in the microfractures, as described earlier.

Moreover, most of the samples can be classified as fair to good petroleum source rocks (Fig. 8c). The overall distribution of the generative potential parameters, $\mathrm{S} 1$ and $\mathrm{S} 2$, and thus the PI, shows a broad range of values (Fig. 8d). These values agree with a thermal maturity corresponding to the oil generation window (Espitalié et al., 1985; Peters, 1986). However, some samples could have undergone either primary migration $(\mathrm{PI}<0.1)$ or impregnation by nonindigenous hydrocarbons $(\mathrm{PI}>0.4)$.

\subsection{Molecular precursors and environmental signature}

Distributions of $n$-alkanes in source rocks can be used to indicate the OM source (Tissot et al., 1977; Peters and Moldowan, 1993). $\mathrm{C}_{15}$ to $\mathrm{C}_{35}$-alkanes are present in all GC traces (Fig. 5). For the representative samples, the distributions of $n$-alkanes show distributions maximizing first in the $n-\mathrm{C}_{17}$ to $n-\mathrm{C}_{20}$ range and second in the $n-\mathrm{C}_{22}$ to $n-\mathrm{C}_{30}$ range. The second modal distribution of $\mathrm{C}_{22}-\mathrm{C}_{30} n$-alkanes shows a slight even-carbon-number preference maximized at the $\mathrm{C}_{24}$ or $\mathrm{C}_{26}$ homologues. This distribution is generally representative of autochthonous aquatic alga and cyanobacteria (Han and Calvin, 1969; Gelpi et al., 1970; Blumer et al., 1971; Brassell et al., 1978; Chaler et al., 2005). We tentatively identified squalane in high relative proportions in the BRK samples (Fig. 5). This isoprenoid has been identified in very reducing marine conditions and is a marker of methanogenic bacteria with other Archaebacteria (Holzer et al. 1979; Brassell et al. 1981). Furthermore, relatively intense peaks of the regular isoprenoids 
norpristane ( $\left.i-\mathrm{C}_{16}\right)$, pristane (Pr: $\left.i-\mathrm{C}_{19}\right)$ and phytane (Ph: $\left.i-\mathrm{C}_{20}\right)$ were found in all samples. These isoprenoids that are primarily derived from the phytol side chain of the chlorophyll molecule (Volkman and Maxwell, 1986) can be used as biomarkers for phytoplankton as well as the oxidoreduction conditions of the environment.

Variations in the redox conditions within the Albian basin are reflected by the fluctuation of isoprenoid concentrations. The $\mathrm{Pr} / \mathrm{Ph}$ ratio (Table 2) is commonly used to evaluate the redox conditions that prevailed at time of deposition (Didyk et al., 1978). $\mathrm{Pr} / \mathrm{Ph}$ values ranging from 0.47 to 2.91 in our samples indicate that the organic matter was deposited under a suboxic environment. The isoprenoid $/ n$-alkane ratios $\left[\mathrm{Pr} / n-\mathrm{C}_{17}\right.$ and $\left.\mathrm{Ph} / n-\mathrm{C}_{18}\right]$ indicate the source rock facies and the thermal maturity (Hunt, 1995). These ratios decrease with maturation as a result of thermal cracking that produces $n$-alkanes and progressively reduces $\operatorname{Pr}$ and $\mathrm{Ph}$ (Tissot et al., 1971). On the other hand, both $\mathrm{Pr} / n-\mathrm{C}_{17}$ and $\mathrm{Ph} / n-\mathrm{C}_{18}$ ratios increase progressively with $n$-alkane biodegradation (Peters et al., 1999). Our results show that low $\operatorname{Pr} / n$ $\mathrm{C}_{17}(<1.13)$ and $\mathrm{Pr} / n-\mathrm{C}_{18}(<1)$ ratios are consistent with an advanced thermal maturity of the OM at these localities (Fig. 9).

Hopanes derive from prokaryotic organisms (Ourisson et al., 1979) such as bacteria and microbes. The nearly identical terpenoid distribution of samples BRK12, GZ10 and HM3, HM16 and HM30 indicates a common origin. The similarity among the $\mathrm{m} / \mathrm{z} 191$ fragmentograms is corroborated by the obvious abundance of tricyclic terpanes, C24 tetracyclic terpanes, the high C27Ts and C29Ts, together with the predominance of C30 17 $\alpha(\mathrm{H})$ diahopane, C30 Hopane and the regular decrease of the C31 to C35 homohopanes (Fig. 6).

These results suggest marine input of OM deposited under suboxic conditions (Peters and Moldowan, 1991). The high abundance of the C23 associated with the C21 tricyclic terpanes with respect to the other tricyclic homologs (Fig. 6) is also indicative of OM deposited in a carbonate marine environment under reducing conditions (Waples and Machihara, 1991). 
The relative abundance of C30 17 $\alpha(\mathrm{H})$-diahopane has been used for geochemical studies of petroleum source rocks and oils (Farrimond and Telnǣs, 1996; Li et al., 2009). Its presence in coals and terrigenous oils has been interpreted as a terrestrial marker (Volkman et al., 1983; Philp and Gilbert, 1986). However, Moldowan et al. (1991) suggested that the C30 17a(H)diahopane may be of bacterial origin, with rearrangement occurring during diagenesis by claymediated acidic catalysis. Thus, its occurrence in oils or rock extracts may indicate bacterial input to sediments containing clay deposited under oxic or suboxic conditions. Furthermore, the $17 \alpha(\mathrm{H})$-diahopane series should be more stable than those of the $17 \alpha(\mathrm{H})$-diahopane with increasing thermal maturity (Kolaczkowska et al., 1990; Moldowan et al., 1991). Li et al. (2009) stated that the concentrations of $17 \alpha(\mathrm{H})$-diahopane in oils or rock extracts is dependent on thermal maturity as well as lithology and environment. These authors defined a Diahopane index (DI) [C30 17 $\alpha(\mathrm{H})$-diahopane/(C30 17 $\alpha(\mathrm{H})$-diahopane + C30 17 $\alpha(\mathrm{H})$-hopane)] that increases with increasing burial depth of the source rocks and can be used to indicate the top of the oil generation window. In the present study, the occurrence of C30 17 $\alpha(\mathrm{H})$-diahopane in the extract of the Albian samples, associated with an elevated H30/H29 ratio (Table 4), tricyclic terpanes, high C27Ts and C29Ts should be consistent with both bacterial origin and thermal maturity of the organic matter deposited with high clastic contents under reducing conditions (Peters et al., 2005). Furthermore, we suggest that the C30 17 $\alpha(\mathrm{H})$-diahopane could be the typical biological marker of the Albian OM in our study. To our knowledge, this compound has never been detected in other Tunisian petroleum source rocks such as the Cenomanian-Turonian Bahloul Formation (OAE2) (Affouri et al., 2013) or the Ypresian Bou Dabbous Formation (Affouri and Montacer, 2014).

The quantitative thermal maturity of the OM can be evaluated by using the Ts/ Ts+Tm ratio. However, lithology and depositional environments can also affect this ratio (Cornford et al., 1983; Schou et al., 1985; Moldowan et al., 1986). In our samples, where facies are similar, 
the relatively high ratio of $\mathrm{Ts} / \mathrm{Ts}+\mathrm{Tm}$ (Table 4) associated with high C29Ts is assumed to reflect the advanced thermal maturity of the Albian OM. This interpretation agrees with the other maturity parameters including Rock-Eval pyrolysis (e.g. Tmax and PI) as well as $n$-alkane distribution and abundant tricyclic terpanes.

The distribution of the $\mathrm{C} 27, \mathrm{C} 28$ and $\mathrm{C} 29(\alpha \alpha 20 \mathrm{R})$ regular steranes can be used as a facies parameter (Huang and Meinschein 1979; Shanmugam, 1985; Killops and Killops, 2005). Marine steranes are derived from the sterols of eukaryotes such as diatoms, dinoflagellates, zooplankton and higher plants (de Leeuw et al., 1989). In our samples, the regular steranes were dominated by the $\mathrm{C} 27$ steranes followed by the $\mathrm{C} 29$ steranes. This feature suggests a mixture of marine and terrestrial OM as revealed by the HI/OI (Fig. 8a) and HI/Tmax (Fig. 8b) cross plots.

Two alternative maturity parameters can be calculated from the sterane series $(\mathrm{m} / \mathrm{z} 217$; Fig. 6) on the basis of progressive isomerization with increasing temperature: the C29 $(14 \alpha(\mathrm{H}), 17 \alpha(\mathrm{H}) 20 \mathrm{~S} /(20 \mathrm{~S}+20 \mathrm{R})) \quad$ ratio $\quad[29 \alpha \mathrm{S} / 29 \alpha(\mathrm{S}+\mathrm{R})]$ and the $\mathrm{C} 29$ $14 \beta(\mathrm{H}), 17 \beta(\mathrm{H})(20 \mathrm{~S}+20 \mathrm{R}) /(14 \beta(\mathrm{H}), 17 \beta(\mathrm{H})(20 \mathrm{~S}+20 \mathrm{R})+14 \alpha(\mathrm{H}) 17 \alpha(\mathrm{H})(20 \mathrm{~S}+20 \mathrm{R}))$ $[29 \beta(\mathrm{S}+\mathrm{R}) /((29 \beta(\mathrm{S}+\mathrm{R})+29 \alpha(\mathrm{S}+\mathrm{R}))]$ ratio (Seifert and Moldowan, 1986). Both isomerization ratios increase with increasing maturity (Mackenzie et al., 1980). Usually, the $29 \alpha \mathrm{S} / 29 \alpha(\mathrm{S}+\mathrm{R})$ ratio reaches an equilibrium value of $0.52-0.55$ near the peak oil generation. The $29 \beta(\mathrm{S}+\mathrm{R}) /((29 \beta(\mathrm{S}+\mathrm{R})+29 \alpha(\mathrm{S}+\mathrm{R}))$ ratio is slower to reach an equilibrium value of ca. 0.70 around peak oil generation (Mackenzie et al., 1980; Peters and Moldowan, 1993; Ramón and Dzou, 1999). Peters and Moldowan, (1993) indicated that this ratio is independent of OM source input. In the present study, the analyzed samples display $29 \alpha \mathrm{S} / 29 \alpha(\mathrm{S}+\mathrm{R})$ sterane ratios between 0.45 and 0.50 , i.e. lower than the equilibrium values (0.52-0.55). All analyzed samples, except one (HM3), have $29 \beta(\mathrm{S}+\mathrm{R}) /((29 \beta(\mathrm{S}+\mathrm{R})+29 \alpha(\mathrm{S}+\mathrm{R}))$ ratios greater than 0.5 but have not reached the equilibrium values (0.67-0.71). Accordingly, these sterane maturity ratios 
indicate that the $\mathrm{OM}$ of the Albian was at maturity levels corresponding to an early oil generation stage (Waples and Machihara, 1990; Peters and Moldowan, 1993). Furthermore, these samples show a high abundance of rearranged C27 diasteranes relative to regular steranes (Fig. 6). The relative abundance of diasteranes to steranes is commonly used to discriminate carbonate from clay-rich source rocks. Therefore, low diasteranes are consistent with anoxic clay-poor or carbonate-rich source rocks (Clark and Philp, 1989), whereas high proportions are usually associated with source rocks, containing abundant clays (Mello et al., 1988). The transformation of sterenes to diasteranes during diagenesis is catalyzed by acidic sites on clays (Kirk and Shaw, 1975; Rubinstein et al., 1975; Sieskind et al., 1979; Grantham and Wakefield, 1988). Moreover, the diasteranes are stable and prevail at higher thermal maturity compared to the regular steranes (Hughes et al., 1985; Goodarzi et al., 1989). In our samples, the relatively high diasterane contents indicate both clay-rich source rock deposited under suboxic conditions and advanced thermal maturity.

\subsection{Structural and paleogeographic control on Albian OAEs in Tunisia}

Repetitive episodes of OM sedimentation are called oceanic anoxic events (OAE) and are mainly known during the Cretaceous (Schlanger and Jenkyns, 1976), Jurassic (Jenkyns, 1985) and Permian/Trias (Grice et al., 2005). The term "black shale" or "black clay" or "bituminous shale" refers to OM-rich formations. This term does not always reflect reality because the sediments deposited during a given period are not necessarily black, nor always of clay nature (Nzoussi-Mbassani, 2003). Several terms have been proposed to designate these OM-rich sediments. For example, the Lower Toarcian OM-rich clays from the Paris Basin in France are known as "schist cartons" or "bituminous schist" (Goy et al., 1979). In Germany, the sediments are called "Posidonienschiefer" while in England, they are called "Jet-Rock". Despite these different vocabularies, the concept of "black shale" remains to date the most widely used, given its genetic connotation. It should be noted that in the Tethyan domain, black 
shales are preserved only in limited sub-basins which favour stagnation and depletion of deepwater oxygen (Baudin and Lachkar 1990; Baudin et al. 1990; Karakitsios, 1995). Several factors may have played a role in creating the specific environmental conditions that favoured the emergence of "OAE" in the Cretaceous. The most notable factor was an extremely hot climate, probably due to high concentrations of atmospheric $\mathrm{CO}_{2}$ caused by increased volcanism (Arthur et al., 1985; Bice et al., 2006; Sinninghe Damsté et al., 2008; Turgeon and Creaser, 2008). The resulting warmer ocean waters probably resulted in halothermal (hot and salty) oceanic circulation rather than thermohaline circulation (Horne, 1999). As a result, these conditions result in lower deep water ventilation rates as hot waters contain less dissolved oxygen. In addition, the rapid expansion of the ocean floor, underwater volcanism and hydrothermal activity would have had a strong effect on ocean circulation (Hays and Pitman, 1973, Paytan et al., 2004).

The high concentrations of organic carbon in black shales were attributed to both the increased preservation of $\mathrm{OM}$ by the anoxic conditions of the water column, probably due to a slow circulation of ocean waters (Bralower and Thierstein 1987, Sinninghe Damsté and Köster, 1998), and increased primary organic productivity (POP) leading to higher rates of OM accumulation and preservation (Schlanger and Jenkyns, 1976). Accordingly, a high POP will also lead to increased oxygen demand for its mineralization, which could exceed the oxidation potential of the ocean and cause anoxia of the water column (Schlanger and Jenkyns, 1976; Kuypers et al. 2002).

The Early Cretaceous sedimentary basin of central Tunisia corresponds to an unstable platform with clastic deposits toward the South and open marine facies to the North (Marie et al., 1984; Dlala, 1999; Rigane et al., 2010). During the Upper Aptian, a major distensive tectonic phase known as the "Aptian Crisis", (Soyer and Tricart, 1987; Rigane et al., 2010) fragmented the northern edge of the Saharan Platform into tilted blocks (Bismuth et al., 1982; 
Martinez et al., 1991). These tilted blocks controlled the palaeogeography of central Tunisia during Albian-Cenomanian times. Furthermore, the reactivation of faults limiting tilted blocks during the Aptian-Albian extension was associated with the ascension of Triassic evaporites. This tectono-sedimentary context controlled the distribution and preservation of organic-rich sequences from central-western to northern Tunisia. As concluded by Boltenhagen et al. (1985a, b) the Kasserine Fault corresponds to the southern limit of a large structural saddle basin that ensures the transition between the carbonate platform of central Tunisia (Zebbag Formation) towards the South and the deep basin of the "Tunisian Trough" (Fahdene Formation) towards the North. In this case, the HM locality can be said to represent the southern proximal limit of this basin. Further to the North, at the BRK locality, the Albian series was deposited in a subsiding graben structure (graben of Mellegue). The Triassic evaporite ascension no doubt played a role in this structural configuration and thus the distribution and preservation of $\mathrm{OM}$ in the Albian successions. This is the case of the GZ locality, where the Fahdene Formation was deposited in a high edged rim syncline basin positioned between Triassic Diapirs (Jebel Chehid and Jebel Thibar Dipirs). Northeast of the "Tunisian Trough", the ASK locality represent the distal and the deepest part of the Albian Basin. All these structural configurations, from South to the Northeast, have influenced the preservation of OM. Therefore, we suggest that OM richness resulted from the installation of an oxygen minimum zone (OMZ) at mid-depth of this basin, and that this OMZ was induced by a high POP, as revealed by the abundance of radiolarian especially around the Mellegue Graben, the GZ and ASK outcrops (Ben Fadhel et al., 2010, 2014). Therefore, the high OM content in these outcrop sections was promoted by both reduced terrigenous input during transgression phases and the spreading of upwelling-induced OMZ that invaded the upper slope and shelf with rising sea level (Schlanger et al., 1987; Arthur and Sageman, 1994). The structural framework as tilted blocks and halokinesis inherited from the Late Aptian tectonics and subsequent sea level rise 
during the early Albian (Weissert and Lini, 1991; Weissert et al., 1998) played a major role in the record of the OAE1b and OAE1c in this southern Tethys margin. These events are comparable to the basal Albian Paquier, in the Vocontian Basin of Southeast France, and the lower Albian Leenhardt, events that have been attributed to elevated primary productivity (Bréhéret, 1994; Erbacher et al., 1999, 2001). These findings suggest that multiple causes, including primary productivity, sea level changes, climatically driven organic carbon burial and structural framework, contributed to the Cretaceous OAE1b and OAE1c in Tunisia. All of these features are summarized in the schematic model presented in Figure 10. Consequently, we suggest that, when sea level rose during the Early Albian transgression (Weissert and Lini, 1991; Weissert et al., 1998), the invaded structurally low areas (grabens and inter-diapiric rimsynclines) represent very deep marine basins that were below the OMZ limits. Therefore, the installation of an OMZ layer at ocean mid-depth, in relationship with upwelling and high POP, coincided with half-graben high structures as well as around Triassic diapir horsts. An expanded and intensified OMZ is suggested to be the main factor controlling the Early Albian sedimentation in the HM and BRK sections. Both localities probably registered the OAE1b in the southern Tethys margin. The oscillations of the OMZ related to fluctuating POP and upwelling nutrient supplies as well as the continental material supply by intensive weathering and seasonal rainfall (Fenner, 2001) could explain both the facies alternations and the OM richness of the sediments. During the Latest Albian time, the OMZ covered a large domain of this relatively deep-marine outer part of a horst and graben basin (Chihaoui et al., 2010). Consequently, the HM locality coincides with the uppermost limit of the OMZ and therefore registers more fluctuations of $\mathrm{OM}$ preservation/non-preservation at this time. During this period, the BRK and ASK localities were in the basin depth corresponding to a position within the OMZ. According to the depositional model suggested, the ASK outcrop stayed in deep water facies of the Tunisian Trough throughout Albian times and within the OMZ. 
In all the studied cross-sections, the OM was a mixture of Type II/III of marine planktonic and continental origin. Moreover, the abundant tricyclic terpanes, C30 $17 \alpha(\mathrm{H})$ diahopane and the distribution of homohopane molecules agreed with a strong bacterial activity under a suboxic environment and thus a high bacterial contribution to this OM.

\subsection{Petroleum exploration implications}

As revealed by the Rock-Eval analysis, the Albian successions of the Lower Fahdene Formation are characterized by fair to good OM richness and petroleum potential. The preserved $\mathrm{OM}$ is predominantly marine planktonic Type II oil and gas prone with some contribution of continental Type III gas prone kerogen. The Tmax, PI and molecular maturity parameters (n-alkane/isoprenoid ratios, C27Ts, C29Ts, and C29 sterane isomerisation) showed that this $\mathrm{OM}$ achieved thermal maturation grades for oil generation. The hydrocarbon exploitation in the Central Atlas of Tunisia started in 1968 by the discoveries of the Douleb, Semmama and Tamesmida oil fields. These oils accumulated in the carbonate reefal facies of the Aptian Serdj Formation reservoir (Hughes and Reed, 1995; Mejri et al., 2006). These authors considered that these oils were sourced from the Lower Fahdene Formation (Albian, Moualha Formation). Belhaj Mohamed et al. (2013) also attributed these oils to the Lower Fahdene Formation. As revealed by Belhaj Mohamed et al. (2013), both crude oil samples and Fahdene source rocks reveal the occurrence of the C30 diahopane in relatively high quantities. In our study, this biomarker was found in all samples. Therefore, we suggest that this compound should be used in oil-source rock correlation as a specific biomarker for oil sourced from the Lower Fahdene source rock. Furthermore, these oil fields are located on horst highs of Jebel Semmama and Jebel Chambi separated by the graben of Foussana-Kasserine (Fig. 1). Taking into account these structures, the best candidate source rock would be the Lower Fahdene Formation similar to that outcropping at the HM locality. As a result, we suggest that the NWSE subsiding graben of Foussana-Kasserine was the pod of the active source rock for these oils. 
Therefore, our results concord with the oil migration pathways suggested by Belhaj Mohamed et al. (2013) and the cross section established by Dhahri et al. (2015; Fig. 3 of these authors). All of these features are synonymous with proven petroleum systems as defined by Magoon and Dow (1994) around the Kasserine area.

\section{CONCLUSIONS}

The organic geochemical analysis of outcrop samples of the Fahdene Formation (Albian to Cenomanian) from central to northern Tunisia is characterised by both regional and vertical differences. The Rock-Eval pyrolysis results showed that most of the studied samples had a Total Organic Carbon (TOC) content high enough to qualify an OAE. The Hydrogen Index

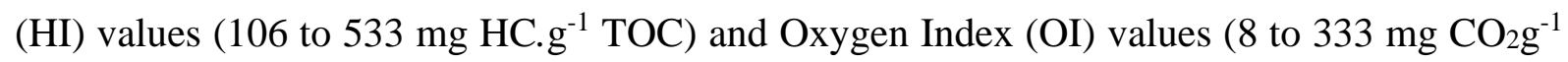
TOC) are typical of a mixed marine planktonic and terrestrial OM origin (Type II/III OM). This $\mathrm{OM}$ is thermally mature, corresponding to the peak of the petroleum generation window in all the studied sections, as revealed by Tmax values between 439 to $453^{\circ} \mathrm{C}$.

However, we registered variations in OM contents vertically along the cross-section and between localities. These variations could be due to several factors: oscillations of both oxic/dysoxic and anoxic conditions that prevailed during the deposition of this formation, the continental material supply by intensive weathering and seasonal rainfall as well as the variation in the expansion of the $\mathrm{OMZ}$ in relation to the primary organic production and seasonal upwelling. Our results show that the Albian OAEs have been registered in the southern Tethys margin of Tunisia. However, the records of these OAEs are diachronic and could be linked to the local basin structural framework that prevailed during the Late Aptian/Early Albian and Late Albian times. Our integrated structural and geochemical results allow us to identify the OAE1b (Late Aptian-Early Albian) and the OAE1c (Latest Albian) in central to northern Tunisia. The OAE1b record is better preserved on the southern edge of the Tunisian Trough, around the HM locality. This event expresses the expansion of the OMZ during the sea level 
rise that invaded the tilted blocks of the HM area. On the other hand, the OAE1b was discreet or absent in the deeper parts of the Tunisian Trough (i.e. ASK locality), in the Triassic diapir horst structures (BRK locality) and in the inter-diapiric basins (GZ locality). These features denoted that the ocean bottom waters were within the OMZ. Despite these aspects, the OAE1c was registered in both the southern edge, at HM, and the central part of the Tunisian Trough, at BRK and GZ. We suggest that the OM richness of the sediments was favoured by the OMZ expansion all over this relatively deep-marine outer part of the basin. Throughout Albian times, the ASK locality registered a deep basin environment within the Tunisian Trough and always within the $\mathrm{OMZ}$. The $\mathrm{OMZ}$ was induced by high marine primary organic productivity, as revealed in thin section observations by abundant radiolarian. We propose that increased plankton productivity during the latest Aptian-early Albian OAE1b and the Latest Albian OAE1c resulted from upwelling of nutrient-enriched waters and volcanism. Furthermore, the thin laminations that were observed both at the macroscopic scale (outcrop) and in thin sections suggested anoxic depositional environments.

In our study, the analysis of molecular fossil biomarkers (n-alkanes, steranes and terpanes) showed that the $\mathrm{OM}$ in the Albian successions was of marine planktonic and bacterial origin (aquatic algae and cyanobacteria). The molecular distributions of the studied samples showed abundant tricyclic terpanes, C30 17 $\alpha(\mathrm{H})$ Diahopane, Hopane and the regular decrease of the C31-C35 homohopane series. All of these features corroborated high bacterial activities in the water column and/or the sea floor, under dysoxic/anoxic deposition environments. However, the continental contribution to this OM cannot be excluded as revealed by the subordinate occurrence of tetracyclic terpanes. The molecular thermal maturity parameters showed that this $\mathrm{OM}$ is thermally mature with respect to the zone of oil generation. 


\section{Acknowledgments}

The work received financial support from the research unit "Georesources, Natural Environments and Global Changes" (GEOGLOB; code: LR13ES23, Tunisia). The authors are deeply grateful to Claude Le Milbeau, CNRS Research Engineer at the Institute of Earth Sciences of Orleans (ISTO - UMR 7327, CNRS-University of Orleans, France) for his assistance with Rock-Eval pyrolysis and GC-MS analysis. We would like to thank anonymous reviewer and P. Fernandes for their corrections and constructive comments. E. Rowley-Jolivet is greatly thanked for corrections to the English.

\section{References}

Affouri, H., Montacer, M. 2014. Organic matter appraisal of the Lower Eocene (Ypresian) Bou Dabbous Formation in Tunisia. Arabian Journal of Geosciences, 7 (12), 5509-5542. DOI: 10.1007/s12517-013-1197-6.

Affouri, H., Montacer, M. Disnar, J.-R. 2013. Organic Geochemistry of the CenomanianTuronian Bahloul Formation Petroleum Source Rock, Central and Northern Tunisia. Resource Geology, 63, 262-287. doi:10.1111/rge.12008

Arthur, M. A., Dean, W. E., Schlanger, S. O. 1985. Variations in the global carbon cycle during the Cretaceous related to climate, volcanism, and changes in atmospheric CO2. In: Sundquist E.T. and Broecker W.S. (Ed.), The Carbon Cycle and Atmospheric CO2: Natural Variations Archean to Present, Geophys. Monogr. Ser., vol. 32, 504- 529, AGU, Washington, D.C.

Arthur, M. A., Silva, I. 1982. Development of widespread organic carbon-rich strata in the Mediterranean Tethys. In: Schlanger S.O. and Cita M.B. (Ed.), Nature of Cretaceous Carbon-Rich Facies, Academic, San Diego, Californian, 7-54.

Arthur, M.A., Jenkyns, H.C., Brumsack, H.J., Schlanger, S.O., 1990. Stratigraphy, geochemistry and paleoceanography of organic carbon-rich Cretaceous sequences. In: 
Ginsburg, R.N., Beaudoin, B. (Eds.), Cretaceous Resources, Events and Rhythms. Kluwer, Dordrecht, 75-119.

Arthur, M.A., Sageman, B.B. 1994. Marine black shales: Depositional mechanisms and environments of ancient deposits, Annu. Rev. Earth Planet. Sci., 22, 499-551.

Batik, P., Donze, P., Ghali, A., Maamouri, A.L., Memmi, L. 1987. Les dépôts crétacés dans le secteur du jebel Trozza. Notes Serv. géol. Tunisie 54, 5-24.

Baudin, F., Herbin, J.P., Vandenbroucke, M., 1990. Mapping and geochemical characterization of the Toarcian organic matter in the Mediterranean Tethys and Middle East. Organic Geochemistry, 16, 677-687.

Baudin, F., Lachkar, G., 1990. Géochimie organique et palynologie du Lias supérieur en zone ionienne (Grèce) exemple d'une sédimentation anoxique conservée dans une paléo-marge en distension. Bulletin de la Société Géologique de France, VI (1), 123-132. doi:10.2113/gssgfbull.VI.1.123

Behar, F., Beaumont, V., De B. Penteado, H.L. 2001. Rock-Eval 6 Technology: Performances and Developments. Oil \& Gas Science and Technology - Rev. IFP, Vol. 56, No. 2, 111 134. https://doi.org/10.2516/ogst:2001013

Belhaj Mohamed, A., Saidi, M., Bendriss, W., Mahloudi S., Bouazizi, I. 2013. Geochemical Evaluation of Hydrocarbons and their Potential Sources in the Central and Meridional Atlas of Tunisia. North Africa Technical Conference \& Exhibition, Cairo, Egypt, 15-17 April 2013. Society of Petroleum Engineers, SPE 164607, 12 p.

Ben Ayed N. 1986. L'évolution tectonique de l'avant-pays de la chaîne alpine de Tunisie du début du Mésozoïque à l'Actuel. Tectonique. Thèse Université Paris Sud - Paris XI. Service géologique de Tunisie (Eds.), Ann. Mines Geo., 32, (1993), 286p. https://tel.archivesouvertes.fr/tel-01009784. 
Ben Ayed, N. 1994. Les décrochements-chevauchements EW et NS convergents de la Tunisie septentrionale: géométrie et essai de reconstitution des conditions de déformation. In : Proceedings of the $4^{\text {th }}$ Tunisian Petroleum Exploration conference, ETAP (Eds.), Mem. 9, 25-37.

Ben Fadhel, M., Layeb, M., Ben Youssef, M., 2010. Upper Albian planktic foraminifera and radiolarian biostratigraphy (Nebeur - northern Tunisia). Comptes Rendus Palevol 9, 73-81.

Ben Fadhel, M., Layeb, M., Hedfi, A., Ben Youssef, M., 2011. Albian oceanic anoxic events in northern Tunisia: Biostratigraphic and geochemical insights, Cretaceous Research, 32, 685699.

Ben Fadhel, M., Zouaghi, T., Amri, A., Ben Youssef, M. 2014. Radiolarian and Planktic Foraminifera Biostratigraphy of the Early Albian Organic Rich Beds of Fahdene Formation, Northern Tunisia. Journal of Earth Science 25 (1), 45-63.

Ben Haj Ali, N., 2005. Les Foraminifères Planctoniques du Crétacé (Hauterivien à Turonien Inférieur) du Tunisie: Systématiques, Biozonations et Précisions Biostratigraphique: [Dissertation]. Université Tunis el Manar, Faculté des Sciences de Tunis, Tunis (in French).

Bice, K.L., Birgel, D., Meyers, P.A., Dahl, K.A., Hinrichs, K.U., Norris, R.D., 2006. A multiple proxy and model study of Cretaceous upper ocean temperatures and atmospheric CO2 concentrations. Paleoceanography 21. doi:10.1029/2005PA001203.

Bismuth, H., Boltenhagen, C., Donze, P., Le Fevre, J., Saint-Maint, P., 1982. Etude sédimentologique et biostratigraphique du Crétacé moyen et supérieur du Jebel Semmama (Tunisie du Centre-Nord), Cret. Res., London 3 (2), 171-185.

Bismuth, H., Boltenhagen, C., Donze, P., Le Fevre, J., Saint-Maint, P., 1981. Le Crétacé moyen et supérieur du Djebel Semmama (Tunisie du Centre-Nord); Microstratigraphie et évolution sédimentologique. Bull. Cent. Rech. Pau - SNPA 5/2,193-267. 
Bismuth, H., Mahjoub, N. 1985: Le Crétacé moyen du jebel Chambi (Tunisie du Centre Nord). Aperçu biostratigraphique et sédimentologique. ler Congr. nat. Sci. Terre (Tunis 1981), 3757.

Blumer, M., Guillard, R. R. L., Chase, T. 1971. Hydrocarbons of marine phytoplankton. Marine Biology, 8(3), 183-189.

Boltenhagen, C. 1985a: Les séquences de sédimentation du Crétacé moyen en Tunisie centrale. ler Congr. nat. Sci. Terre (Tunis 1981), 55-71.

Boltenhagen, C., 1985b. Paléogéographie du Crétacé moyen de la Tunisie centrale, 1er congr. Nat. Sci. Terre (Tunis 1981), 97-114.

Bolze, J., Burollet, P.F., Castany, G. 1952. Le sillon Tunisien, 2nd Ed. XIXe Congrès Géologique International, Monographies régionales, n॰ 5 .

Bordenave, M. L. 1993. Applied petroleum geochemistry. Eds. Technip, Paris.

Bouaziz, S., Barrier, E., Soussi, M., Turki, M.M., Zouari, H., 2002. Tectonic evolution of the northern African margin in Tunisia from paleostress data and sedimentary record. Tectonophysics 357, 227-253.

Boughdiri, M., Cordey, F., Sallouhi, H., Maâlaoui, K., Masrouhi, A., Soussi, M. 2007. Jurassic radiolarian-bearing series of Tunisia: biostratigraphy and significance to western Tethys correlations, Swiss J. Geosciences 100, 431-441. DOI : 10.1007/s00015-007-1237-x

Boukadi, N. 1996. Schéma structural nouveau pour le Nord de la Tunisie. In: Proceedings of the 5th Tunisian Petroleum Exploration conference, ETAP (Eds.) Mem. 11, 91-100.

Boukadi, N., Zargouni, F., Ruhland, M. 1992. Cinématique et évolution tectonique des failles en baïonnette dans l'Atlas de Tunisie: transtension, halocinèse et transpression. Comptes rendus de l'Académie des sciences, Série 2, Mécanique, Physique, Chimie, Sciences de l'univers, Sciences de la Terre, 315 (13), 1755-1760. 
Bralower, T. J., CoBabe, E., Clement, B., Sliter, W. V., Osburn, C. L., Longoria, J. 1999. The record of global change in mid-Cretaceous (Barremian-Albian) sections from the Sierra Madre, northeastern Mexico. Journal of Foraminiferal Research, 29 (4), 418-437.

Bralower, T. J., Thierstein, H. R. 1987. Organic carbon and metal accumulation rates in Holocene and mid-Cretaceous sediments: palaeoceanographic significance. Geological Society, London, Special Publications, 26 (1), 345-369.

Bralower, T.J., Sliter,W.V., Arthur, M.A., Leckie, R.M., Allard, D.J., Schlanger, S.O., 1993. Dysoxic/anoxic episodes in the Aptian-Albian, In: Pringle, M.S., Sager, W.W., Sliter, W.V., Stein, S. (Eds.), The Mesozoic Pacific: Geology, Tectonics, and Volcanism. American Geophysical Union Monograph, vol. 77, 5-37.

Brassell, S. C., Eglinton, G., Maxwell, J. R., Philp, R. P. 1978. Natural background of alkanes in the aquatic environment. Aquatic pollutants: transformation and biological effects, 69-86.

Brassell, S. C., Wardroper, A. M. K., Thomson, I. D., Maxwell, J. R., Eglinton, G. 1981. Specific acyclic isoprenoids as biological markers of methanogenic bacteria in marine sediments. Nature, 290 (5808), 693-696.

Bréhéret, J.-G., 1985. Indices d'un événement anoxique étendu a la Tethys alpine, à l'Albien inférieur (événement Paquier). Comptes Rendus Académie des Sci. Paris, Série II, Mécanique, Phys. Chim. Sci. l'univers, Sci. la terre 300, 355-358.

Bréhéret, J.-G., 1994. The mid-Cretaceous organic-rich sediments from the Vocontian zone of the French Southeast Basin. In: Mascle A. (Eds.), Hydrocarbon and Petroleum Geology of France, Springer-Verlag, New York, 295-320. doi:10.1007/978-3-642-78849-9_21.

Bréhéret, J.-G., Caron, M., Delamette, M., 1986. Niveaux riches en matière organique dans l'Albien vocontien; quelques caractères du paléoenvironnement; essai d'interprétation génétique. Doc. du Bur. Rech. Géologiques Minières 110, 141-191. 
Burollet, P. F. 1956. Contribution à l'étude stratigraphique de la Tunisie Centrale. Ann. Mines Géol., Tunisie, 18, 1-345.

Burollet, P. F. 1973. Importance des facteurs salifères dans la tectonique tunisienne. Ann. des mines et de la géologie, Livre du Jubilé de M. Solignac, 26, 111-120.

Burollet, P. F., Ellouz, N., 1986. L'évolution des bassins sédimentaires de la Tunisie centrale et orientale, Bull. Centres Rech. Pau - SNPA, 10, 49-68.

Burollet, P. F., Sainfeld, P. 1956. Carte géologique de la Tunisie au 1/50.000, feuille $\mathrm{n}^{\circ}$ 44, le Kef. Notice explicative, 1.

Burollet, P.F., Memmi, L., M'Rabet, A., 1983, Le Crétacé inférieur de Tunisie. Aperçu stratigraphique et sédimentologique, Zitteliana 10, 255-264.

Casey, R., Bayliss, H.M. Simpson, M.I. 1998. Observations on the lithostratigraphy and ammonite succession of the Aptian (Lower Cretaceous) Lower Greensand of ChaleBay, Isle of Wight, UK. Cretaceous Research, 19, 511-535.

Chaler, R., Dorronsoro, C., Grimalt, J.O., Agirrezabala, L.M., Fernandez-Mendiola P.A., Garcia-Mondejar, J., Gomez-Perez, I., Lopez-Horgue, M. (2005) - Distributions of C22-C30 even-carbon-number n-alkanes in Ocean Anoxic Event 1 samples from the BasqueCantabrian Basin. Naturwissenschaften 92, 221-225. doi 10.1007/s00114-005-0616-2

Chihaoui, A., 2009. La Transgression Albienne dans la région de Tajerouine en Tunisie Centrale: Stratigraphie, Sédimentologie et Tectonique Synsédimentaire: Doctorate Thesis, Université Joseph-Fourier, Grenoble I, Français. https://tel.archives-ouvertes.fr/tel00470863.

Chihaoui, A., Jaillard, E., Latil, J.L., Zghal, I., Susperregui, A.S., Touir, J., Ouali, J., 2010. Stratigraphy of the Hameima and lower Fahdene Formations in the Tadjerouine area (Northern Tunisia). Jounal of African Earth Sciences, 58, 387-399. 
Chikhaoui, M. 1988. Succession distension compression dans le sillon tunisien, secteur de Nebeur-El Kef, rôle des extrusions triasiques précoce lors des serrages alpins. These Doct. Université de Nice, France, 143 p.

Chikhaoui, M., Jallouli, Ch., Turki, M.M., Soussi, M., Braham, A., Zaghbib-Turki, D. 2002. L'affleurement triasique du Debadib-Ben Gasseur (Nord-Ouest de la Tunisie) : diapir enraciné à épanchements latéraux dans la mer Albienne, replissé au cours des phases de compression tertiaires. C. R. Geoscience, 334, 1129-1133.

Chikhaoui, M., Turki, M., Delteil, J. 1991. Témoignages de la structurogenèse de la marge téthysienne en Tunisie, au Jurassique terminal-Crétacé (Région du Kef, Tunisie septentrionale). Géologie méditerranéenne, 18(3), 165-180.

Chikhaoui, M., Turki, M.M., 1996. Rôle et importance de la fracturation subméridienne dans les déformations crétacées et alpines de la zone des diapirs (Tunisie septentrionale), Journal of African Earth Sciences 2, 271-280.

Clark, J. P., Philp, R. P. 1989. Geochemical characterization of evaporite and carbonate depositional environments and correlation of associated crude oils in the Black Creek Basin, Alberta. Bulletin of Canadian Petroleum Geology, 37(4), 401-416.

Coccioni, R., Galeotti, S. 1993. Orbitally induced cycles in benthonic foraminiferal morphogroups and trophic structure distribution patterns from the Late Albian "Amadeus Segment” (Central Italy). Journal of Micropalaeontology, 12(2), 227-239.

Cornford, C., Morrow, J. A., Turrington, A., Miles, J. A., Brooks, J. 1983. Some geological controls on oil composition in the UK North Sea. Geological Society, London, Special Publications, 12(1), 175-194.

de Leeuw, J.W., Cox, H.C., van Graas, G., van de Meer, F.W., Peakman, T.M., Baas, J.M.A., van de Graaf, B., 1989. Limited double bond isomerisation and selective hydrogenation of 
sterenes during early diagenesis. Geochim. Cosmochim. Acta 53, 903-909. doi:10.1016/0016-7037(89)90034-3.

Dhahri, F., Tanfous, D., Gabtni, H., Boukadi, N., 2015. Structural and geodynamic study in central Tunisia using field and geophysical data: new structural interpretation of the $\mathrm{N}-\mathrm{S}$ axis and associated Atlassic structures. Int. J. Earth Sci. 104, 1819-1835. doi:10.1007/s00531-015-1159-1.

Didyk, B. M., Simoneit, B. R. T., Brassell, S. C., Eglinton, G. 1978. Organic geochemical indicators of palaeoenvnonmental conditions of sedimentation. Nature, 272, 216-222.

Dlala, M. 1999. La tectonique crétacée et son implication sur la structuration de L'Atlas tunisien central: exemple d'application sur le bassin de Foussana et Bled Zelfane. Notes Serv. Géol., Tunisie, 66, 89-102.

Dunham, R.J. 1962. Classification of carbonate rocks according to depositional textures.

Durand, B., 1980. Kerogen: Insoluble organic matter from sedimentary rocks. Eds. Technip, Paris, France.

Durand, B., 1993. Composition and structure of organic matter in immature sediments. In Bordenave, M. L. (Eds.) Applied petroleum geochemistry, Technip, Paris, 77-100.

Ekweozor, C.M., Strausz, O.P. 1982. 18,19-Bisnor-13ßH, $14 \alpha \mathrm{H}$-cheilanthane: a novel degraded tricyclic sesterterpenoid-type hydrocarbon from Athabasca oil sands. Tetrahedron Lett 23, 2711-2714.

El Euchi, H. 1993. La Tunisie du Centre-Ouest de l'Aptien à l'Actuel: Tectonique coulissante, dynamique sédimentaire associée et évolution du champ de contraintes Mio-PlioQuaternaire (Doctoral dissertation, $\mathrm{PhD}$ thesis University of Tunis II).

Erbacher, J., Hemleben, C., Huber, B.T., Markey, M. 1999. Correlating environmental changes during early Albian oceanic anoxic event 1B using benthic foraminiferal paleoecology. Marine Micropaleontology, 38(1), 7-28. 
Erbacher, J., Huber, B.T., Norris, R.D., Markey, M., 2001. Increased thermohaline stratification as a possible cause for an ocean anoxic event in the Cretaceous period. Nature 409, 325-327

Erbacher, J., Thurow, J., Littke, R. 1996. Evolution patterns of radiolaria and organic matter variations: a new approach to identify sea-level changes in mid-Cretaceous pelagic environments. Geology, 24(6), 499-502.

Espitalié, J., Deroo, G., Marquis, F., 1985. La pyrolyse Rock- Eval et ses applications (deuxième partie). Revue de l'Institut Français du Pétrole, 40, 755-784.

Fakhraoui, M., Ghanmi, M., Htira, N. 1998. Notice explicative de la carte géologique de la Tunisie à 1/50000, Feuille ${ }^{\circ} 39$, Nebeur. Office National des mines, Service géologique de Tunisie, 30p.

Farrimond, P., Telnǣs, N., 1996. Three series of rearranged hopanes in Toarcian sediments (Northern Italy). Org. Geochem. 25, 165-177

Fenner, J. 2001. Middle and Late Albian geography, oceanography, and climate and the setting of the Kirchrode I and II borehole sites. Palaeogeography, Palaeoclimatology, Palaeoecology, 174(1), 5-32.

Fiet, N., Beaudoin, B., Parize, O. 2001. Lithostratigraphic analysis of Milankovitch cyclicity in pelagic Albian deposits of central Italy: implications for the duration of the stage and substages. Cretaceous Research, 22(3), 265-275.

Folk, R. L. 1962. Spectral subdivision of limestone types.

Galeotti, S., Sprovieri, M., Coccioni, R., Bellanca, A., Neri, R., 2003. Orbitally modulated black shale deposition in the upper Albian Amadeus Segment (Central Italy): a multiproxy reconstruction. Palaeogeography, Palaeoclimatology, Palaeoecology 190, 441-458.

Gelpi, E., Schneider, H., Mann, J., Oro, J. 1970. Hydrocarbons of geochemical significance in microscopic algae. Phytochemistry, 9 (3), 603-612. 
Goodarzi, F., Brooks, P. W., Embry, A. F. 1989. Regional maturity as determined by organic petrography and geochemistry of the Schei Point Group (Triassic) in the western Sverdrup Basin, Canadian Arctic Archipelago. Marine and Petroleum Geology, 6 (4), 290-302.

Goy, G., Noël, D., Busson, G. 1979. Les conditions de sédimentation des schistes-carton Toarclen Inf. du Bassin de Paris déduites de l'étude des nannofossiles calcaires et des diagraphies. Docu. lab. Géol. Fac. Sci. Lyon, 75, 33-57.

Grantham, P.J., Wakefield, L.L. 1988. Variations in the sterane carbon number distributions of marine source rock derived crude oils through geological time. Organic Geochemistry, 12(1), 61-73.

Grice, K., Cao, C., Love, G. D., Böttcher, M. E., Twitchett, R. J., Grosjean, E., ..., Jin, Y. 2005. Photic zone euxinia during the Permian-Triassic superanoxic event. Science, 307(5710), 706-709.

Grippo, A., Fischer, A. G., Hinnov, L. A., Herbert, T. D., Silva, I. P. 2004. Cyclostratigraphy and chronology of the Albian stage (Piobbico core, Italy). In: Cyclostratigraphy: Approaches and Case Histories, SEPM, Special Publication 81, ISBN 1-56576-108-1, 57-81.

Haig, D. W., Lynch, D. A. 1993. A late early Albian marine transgressive pulse over northeastern Australia, precursor to epeiric basin anoxia: foraminiferal evidence. Marine Micropaleontology, 22(4), 311-362.

Han, J., Calvin, M. 1969. Hydrocarbon distribution of algae and bacteria, and microbiological activity in sediments. Proceedings of the National Academy of Sciences, 64 (2), 436-443.

Hancock, J. 2001. A proposal for a new position for the Aptian/Albian boundary. Cretaceous Research, 22, 677-683.

Hatira, N., Smati, A., Mansouri, A., Perthuisot, V., Rouvier, H. 2000. Le Trias a caractère extrusif de la zone des dômes; exemple de la structure de Debadib-Ben Gasseur (Tunisie septentrionale). Bulletin de la Société géologique de France, 171 (3), 319-326. 
Hays, J. D., Pitman, W. C. 1973. Lithospheric plate motion, sea level changes and climatic and ecological consequences. Nature, 246 (5427), 18-22.

Herbert, T.D., Fischer, A.G. 1986. Milankovitch climatic origin of mid-Cretaceous black shale rhythms in central Italy. Nature, 321 (6072), 739-743.

Holzer, G., Oro, J., Tornabene, T.G. 1979. Gas chromatographic_mass spectrometric analysis of neutral lipids from methanogenic and thermoacidophilic bacteria. Journal of Chromatography A, 186, 795-809.

Horne, D.J. 1999. Ocean circulation modes of the Phanerozoic: implications for the antiquity of deep-sea benthonic invertebrates. Crustaceana, 72 (8), 999-1018.

Huang, W. Y., Meinschein, W. G. 1979. Sterols as ecological indicators. Geochimica et Cosmochimica acta, 43 (5), 739-745.

Huber, B.T., Leckie, M., 2011. Planktic foraminiferal species turnover across deep-sea Aptian/Albian boundary sections. J. Foraminifer. Res. 41, 53-95. http://dx.doi.org/10.2113/gsjfr.41.1.53.

Hughes, W.B., Holba, A.G., Miller, D.E., Richardson, J.S. 1985. Geochemistry of greater Ekofisk crude oils. In: Petroleum Geochemistry in Exploration of the Norwegian Shelf, Springer Netherlands, 75-92. doi:10.1007/978-94-009-4199-1_5

Hughes, W.B., Reed, J.D. 1995. Oil and source rock geochemistry and exploration implications in northern Tunisia. In: Proceedings of the seminar on source rocks and hydrocarbon habitat in Tunisia. ETAP (Eds.), Mem. 10, 49-67.

Hunt, J.M. 1995. Petroleum Geochemistry and Geology. Freeman, W.H., and Company, New York, 743p.

Jaillard, E., Dumont, T., Ouali, J., Bouillin, J.-P., Chihaoui, A., Latil, J.-L., Arnaud, H., ArnaudVanneau, A., Zghal, I. 2013. The Albian tectonic "crisis" in Central Tunisia: Nature and chronology of the deformations. Journal of African Earth Sciences, 85, 75-86. 
Jauzein, A. 1967. Contribution à l'étude géologique des confins de la dorsale tunisienne (Tunisie septentrionale). Ann. Min. Géol. (Tunis) 22/4.

Jenkyns, H.C. 1980. Cretaceous anoxic events: from continents to oceans. Journal of the Geological Society, 137(2), 171-188.

Jenkyns, H.C. 1985. The Early Toarcian and Cenomanian-Turonian anoxic events in Europe: comparisons and contrasts. Geologische Rundschau, 74(3), 505-518.

Jenkyns, H.C. 2003. Evidence for rapid climate change in the Mesozoic-Palaeogene greenhouse world, Philos. Trans. R. Soc. London, Ser. A, 361, 1885-1916,

Jenkyns, H.C. 2010. Geochemistry of oceanic anoxic events, Geochem. Geophys. Geosyst., 11, Q03004, doi:10.1029/2009GC002788.

Kadri, A., Ben Haj Ali, M. 1999. Eléments de réflexion sur les linéaments tectoniques EstOuest et Nord-Sud et les grabens associés en Tunisie septentrionale. Notes du service géologique de Tunisie, 65, 131-140.

Karakitsios, V. 1995. The influence of preexisting structure and halokinesis on organic matter preservation and thrust system evolution in the Ionian Basin, Northwest Greece. AAPG bulletin, 79 (7), 960-980.

Kennedy, W.J., Gale, A.S., Bown, P.R., Caron, M., Davey, R J., Gröcke, D., Wray, D.S. 2000. Integrated stratigraphy across the Aptian-Albian boundary in the Marnes Bleues, at the Col de Pré-Guittard, Arnayon (Drôme), and at Tartonne (Alpes-de-Haute-Provence), France: a candidate Global Boundary Stratotype Section and Boundary Point for the base of the Albian Stage. Cretaceous Research 21, 591-720.

Killops, S., Killops, V. 2005. Chemical stratigraphic concepts and tools. Introduction to Organic Geochemistry, Second Edition, 166-245. doi:10.1002/9781118697214.ch3

Kirk, D. N., Shaw, P. M. 1975. Backbone rearrangements of steroidal 5-enes. Journal of the Chemical Society, Perkin Transactions 1, (22), 2284-2294. 
Kolaczkowska, E., Slougui, N. E., Watt, D. S., Maruca, R. E., Moldowan, J. M. 1990. Thermodynamic stability of various alkylated, dealkylated and rearranged $17 \alpha$-and $17 \beta-$ hopane isomers using molecular mechanics calculations. Organic Geochemistry, 16(4-6), 1033-1038.

Kuypers, M.M., Pancost, R.D., Nijenhuis, I.A., Sinninghe Damsté, J.S., 2002. Enhanced productivity led to increased organic carbon burial in the euxinic North Atlantic basin during the late Cenomanian oceanic anoxic event. Paleoceanography, 17, 1051

Lafargue, E., Marquis, F., Pillot, D. 1998. Rock-Eval 6 applications in hydrocarbon exploration, production, and soil contamination studies. Revue de l'institut français du pétrole, 53(4), 421-437.

Leckie, R.M., Bralower, T.J., Cashman, R. 2002. Oceanic anoxic events and plankton evolution: biotic response to tectonic forcing the mid-Cretaceous, Paleoceanography 17(3), $1-29$.

Lehmann, J., Heldt, M., Bachmann, M., Negra, M.E.H. 2009. Aptian (Lower Cretaceous) biostratigraphy and cephalopods from north central Tunisia. Cretaceous Research, 30(4), 895-910.

Li, M., Wang, T., Liu, J., Zhang, M., Lu, H., Ma, Q., Gao, L. 2009. Biomarker 17a(H)diahopane: A geochemical tool to study the petroleum system of a Tertiary lacustrine basin, Northern South China Sea. Applied Geochemistry, 24(1), 172-183.

M'Rabet, A., 1981. Stratigraphie, sédimentation et diagenèse carbonatée des séries du crétacé inférieur de Tunisie centrale. Thèse Doct. és- sciences, univ. Paris sud Orsay, 540p.

M'Rabet, A., Mejri, F., Burollet, P.F., Memmi, L., Chahdoul, H., 1995. Recueil des coupes types de Tunisie. Crétacé. ETAP (Eds.), Mem. 3.

Mackenzie, A. S., Patience, R. L., Maxwell, J. R., Vandenbroucke, M., Durand, B. 1980. Molecular parameters of maturation in the Toarcian shales, Paris Basin, France-I. Changes 
in the configurations of acyclic isoprenoid alkanes, steranes and triterpanes. Geochimica et Cosmochimica Acta, 44(11), 1709-1721.

Magoon, L.B., Dow, W.G. 1994. The Petroleum System: Chapter 1: Part I. Introduction. In: The Petroleum System-From Source to Trap, AAPG memoir 60, 3-24.

Marie, J., Trouve, Ph., Desforges, G., Dufaure, Ph., 1984. Nouveaux éléments de paléogéographie du Crétacé de Tunisie. C.F.P. Total, Paris, Notes et Mémoires 19.

Martinez, C., Chikhaoui, M., Truillet, R., Ouali, J. et Creuzot, R.B., 1991. Le contexte géodynamique de la distension albo-aptienne en Tunisie septentrionale et centrale : structuration éocrétacée de l'Atlas tunisien. Eclogae geol. Helv., 84, 61-82.

Mejri, F., Burollet, P.F., Ben Ferjani, A. 2006. Petroleun Geology of Tunisia, a renewed synthesis. ETAP (Eds.), Mem. 22, 230p.

Mello, M. R., Telnaes, N., Gaglianone, P. C., Chicarelli, M. I., Brassell, S. C., Maxwell, J. R. 1988. Organic geochemical characterisation of depositional palaeoenvironments of source rocks and oils in Brazilian marginal basins. Organic geochemistry, 13(1-3), 31-45.

Memmi, L. 1999. L'Aptien et l'Albien de Tunisie biostratigraphie a partir des ammonites. Bulletin de la Société géologique de France, 170(3), 303-309.

Moldowan, J.M., Fago, F.J., Carlson, R.M., Young, D.C., Duvne, G., Clardy, J., Schoell, M., Pillinger C.T., Watt, D.S. 1991. Rearranged hopanes in sediments and petroleum. Geochimica et Cosmochimica Acta, 55(11), 3333-3353.

Moldowan, J.M., Sundararaman, P., Schoell, M. 1986. Sensitivity of biomarker properties to depositional environment and/or source input in the Lower Toarcian of SWGermany. Organic Geochemistry, 10(4-6), 915-926.

Müller, G., Gastner, M. 1971. The'Karbonat-Bombe', a simple device for the determination of carbonate content in sediment, soils, and other materials. Neues Jahrbuch für MineralogieMonatshefte, 10, 466-469. 
Mutterlose, J., Bornemann, A., Luppold, F. W., Owen, H. G., Ruffell, A., Weiss, W., Wray, D. 2003. The Vöhrum section (northwest Germany) and the Aptian/Albian boundary. Cretaceous Research, 24(3), 203-252.

Nzoussi-Mbassani, P. 2003. Le Cénomano-Turonien de l'Atlantique Nord (bassin du Sénégal): environnement de dépôt et évolution diagénétique: implications pétrolières. Thèse Doctorat, Université Orléans, France, 234p.

Ourisson, G., Albrecht, P., Rohmer, M. 1979. The hopanoids: palaeochemistry and biochemistry of a group of natural products. Pure and Applied Chemistry, 51(4), 709-729.

Paytan, A., Kastner, M., Campbell, D., Thiemens, M. H. 2004. Seawater sulfur isotope fluctuations in the Cretaceous. Science, 304(5677), 1663-1665.

Perthuisot, V. 1978. Dynamique et pétrogenèse des extrusions triasiques de Tunisie septentrionale. Travaux du Laboratoire de Géologie 12, 312.

Perthuisot, V. 1981. Diapirism in northern Tunisia. Journal of Structural Geology, 3(3), 231235.

Perthuisot, V., Aoudjehane, M., Bouzenoune, A., Hatira, N., Laatar, E., Mansouri, A., Thibieroz, J. 1998. Les corps triasiques des monts du Mellegue (confins algero-tunisiens); sont-ils des diapirs ou des "glaciers de sel"?. Bulletin de la Société géologique de France, 169(1), 53-61.

Peters, K.E. 1986. Guidelines for evaluating petroleum source rock using programmed pyrolysis. AAPG bulletin, 70(3), 318-329.

Peters, K.E., Casa, M.R. 1994. Applied source rock geochemistry. In: Magoon, L. B. and Dow, W. G. (ed.) The petroleum system-from source to trap. AAPG Bull., 60, 93-120.

Peters, K.E., Fraser, T.H., Amris, W., Rustanto, B., Hermanto, E. 1999. Geochemistry of crude oils from eastern Indonesia. AAPG bulletin, 83(12), 1927-1942. 
Peters, K.E., Moldowan, J.M. 1991. Effects of source, thermal maturity, and biodegradation on the distribution and isomerization of homohopanes in petroleum. Organic geochemistry, 17(1), 47-61.

Peters, K.E., Moldowan, J.M., 1993. The biomarker guide: interpreting molecular fossils in petroleum and ancient sediment. Prentice Hall, Englewood Cliffs, NJ, 347p.

Peters, K.E., Walters, C.C., Moldowan, J.M. 2005. The Biomarker Guide. K.E. Peters, C.C. Walters and J.M. Moldowan (Eds.), Cambridge University Press, Cambridge, UK.

Philip, H., Andrieux, J., Dlala, M., Chihi, L., Ben Ayed, N. 1987. Evolution tectonique mioplio-quaternaire du fossé de Kasserine (Tunisie centrale): implications sur l'évolution géodynamique récente de la Tunisie. Bulletin Société Géologique, France, (8), II/4,559-568.

Philp, R.T., Gilbert, T.D. 1986. Biomarker distributions in Australian oils predominantly derived from terrigenous source material. Organic Geochemistry, 10(1-3), 73-84.

Pratt, L. M., King, J. D. 1986. Variable marine productivity and high eolian input recorded by rhythmic black shales in Mid-Cretaceous pelagic deposits from central Italy. Paleoceanography, 1(4), 507-522.

Racki, G., Cordey, F. 2000. Radiolarian palaeoecology and radiolarites: is the present the key to the past?. Earth-Science Reviews, 52(1), 83-120.

Ramón, J.C., Dzou, L.I. 1999. Petroleum geochemistry of Middle Magdalena Valley, Colombia. Organic geochemistry, 30(4), 249-266.

Ricken, W. 1993. Input variation in rhythmically bedded sediment. In Sedimentation as a Three-Component System: Organic Carbon, Carbonate, Noncarbonate, Springer-Verlag (Eds.), Berlin, Heidelberg, 59-79. https://doi.org/10.1007/BFb0117861

Rigane, A., Feki, M., Gourmelen, C., 2005. Structural and paleogeographic evolution in central Tunisia in the Cretaceous. Aptian-Turonian events in Central Tunisia. Pre-symposium field trip. Géolgie Alpine, colloque et excursions, Grenoble, vol. 5, 5-10. 
Rigane, A., Feki, M., Gourmelen, C., Montacer, M. 2010. The «Aptian Crisis » of the SouthTethyan margin: New tectonic data in Tunisia. Journal of African Earth Sciences 57, 360366.

Rigane, A., Gourmelen, C., 2011. Inverted intracontinental basin and vertical tectonics: The Saharan Atlas in Tunisia. Journal of African Earth Sciences 61, 109-128. doi:10.1016/j.jafrearsci.2011.05.003.

Rubinstein, I., Sieskind, O., Albrecht, P. 1975. Rearranged sterenes in a shale: occurrence and simulated formation. Journal of the Chemical Society, Perkin Transactions 1, (19), 18331836.

Sabatino, N., Coccioni, R., Manta, D. S., Baudin, F., Vallefuoco, M., Traina, A., Sprovieri, M. 2015. High-resolution chemostratigraphy of the late Aptian-early Albian oceanic anoxic event (OAE 1b) from the Poggio le Guaine section (Umbria-Marche Basin, central Italy). Palaeogeography, Palaeoclimatology, Palaeoecology, 426, 319-333.

Sageman, B.B., Gardner, M.H., Armentrout, J. M., Murphy, A. E. 1998. Stratigraphic hierarchy of organic carbon-rich siltstones in deep-water facies, Brushy Canyon Formation (Guadalupian), Delaware Basin, West Texas. Geology, 26(5), 451-454.

Sainfeld, P. 1951. Carte géologique de la Tunisie au 1/50 000. Feuille 31, Ouargha. Notice explicative. Annales des Mines et de la Géologie, Service géologique de Tunisie (Eds.), Tunis.

Schlanger, S.O., Arthur, M.A., Jenkyns, H.C., Scholle, P.A. 1987. The Cenomanian-Turonian Oceanic Anoxic Event, I. Stratigraphy and distribution of organic carbon-rich beds and the marine $\delta 13 \mathrm{C}$ excursion. Geological Society, London, Special Publications, 26(1), 371-399.

Schlanger, S.O., Jenkyns, H.C. 1976. Cretaceous oceanic anoxic events: causes and consequences. Geologie en mijnbouw, 55 (3-4), 179-184. 
Schou, L., Eggen, S., Schoell, M. 1985. Oil-oil and oil-source rock correlation, Northern North Sea. In: Petroleum Geochemistry in Exploration of the Norwegian Shelf, Springer Netherlands, 101-117.

Seifert, W.K., Moldowan, J.M. 1986. Use of biological markers in petroleum exploration. In: Johns, R.B. (Eds.) Methods in Geochemistry and Geophysics, 24, 261-290.

Shanmugam, G., 1985. Significance of coniferous rain forest and related organic matter in generating commercial quantities of oil, Gippsland Basin, Australia. AAPG Bull., 69, 12411254.

Sieskind, O., Joly, G., Albrecht, P. 1979. Simulation of the geochemical transformations of sterols: superacid effect of clay minerals. Geochimica et Cosmochimica Acta, 43(10), 16751679.

Silva, L.P., Ripepe, M., Tornaghi, M. E. 1989. Planktonic foraminiferal distribution record productivity cycles: evidence from the Aptian-Albian Piobbico core (central Italy). Terra nova, 1(5), 443-448.

Sinninghe Damsté, J. S., Köster, J. 1998. A euxinic southern North Atlantic Ocean during the Cenomanian/Turonian oceanic anoxic event. Earth and Planetary Science Letters, 158(3), $165-173$

Sinninghe Damsté, J.S., Ossebaar, J., Schouten, S., Verschuren, D. 2008. Altitudinal shifts in the branched tetraether lipid distribution in soil from Mt. Kilimanjaro (Tanzania): Implications for the MBT/CBT continental palaeothermometer. Organic Geochemistry, 39(8), 1072-1076.

Snoke, A. W., Schamel, S., Karasek, R. M. 1988. Structural evolution of Djebel Debadib anticline: A clue to the regional tectonic style of the Tunisian Atlas. Tectonics, 7(3), 497516. 
Soyer, C., Tricart, P. 1987. La crise aptienne en Tunisie centrale: approche paléostructurale aux confins de l'Atlas et de l'Axe Nord-Sud. Comptes rendus de l'Académie des sciences. Série 2, Mécanique, Physique, Chimie, Sciences de l'univers, Sciences de la Terre, 305(4), 301305.

Tissot, B., Oudin, J.L., Pelet, R. 1971. Critères d'origine et d'évolution des pétroles. Application à l'étude géochimique des bassins sédimentaires. Advances in organic geochemistry, 113134.

Tissot, B., Pelet, R., Rouache, J., Combaz, A., 1977. Utilization des alcanes comme fossiles géochimiques indicateurs des environnements géologique. A.A.P.G.Bull., 55, 2177-2193.

Tissot, B., Welte, D.H. 1978. Petroleum occurrence and formation. Springer Berlin Heidelberg.

Tissot, B.P., Welte, D.H. 1984. Diagenesis, catagenesis and metagenesis of organic matter. In: Petroleum Formation and Occurrence, Springer Berlin Heidelberg, 69-73.

Tsikos, H., Jenkyns, H.C., Walsworth-Bell, B., Petrizzo, M.R., Forster, A., Kolonic, S., ..., Damsté, J. S. 2004. Carbon-isotope stratigraphy recorded by the Cenomanian-Turonian Oceanic Anoxic Event: correlation and implications based on three key localities. Journal of the Geological Society, 161(4), 711-719.

Turgeon, S. C., Creaser, R. A. 2008. Cretaceous oceanic anoxic event 2 triggered by a massive magmatic episode. Nature, 454(7202), 323.

Tyszka, J. 2009. Foraminiferal response to seasonality modulated by orbital cycles in the Cretaceous mid-latitudes: the Albian record from the Lower Saxony Basin. Palaeogeography, Palaeoclimatology, Palaeoecology, 276(1), 148-159.

Vanderbroucke, M., Behar, F., San Torcuato, A., Rullkötter, J. 1993. Kerogen maturation in a reference kerogen Type II series: the Toarcian shales of the Hils syncline, NW Germany. Organic geochemistry, 20(7), 961-972.

Vatan, A. (1967). Manual of sedimentology. Technip: Paris, France. 
Volkman, J.K., Alexander, R., Kagi, R.I., Rullkötter, J. 1983. GC-MS characterisation of C27 and C28 triterpanes in sediments and petroleum. Geochimica et Cosmochimica Acta, 47 (6), 1033-1040.

Volkman, J.K., Maxwell, J.R. 1986. Acyclic isoprenoids as biological markers. Methods in geochemistry and geophysics, 24, 1-42.

Wagner, T., Herrle, J.O., Sinninghe Damsté, J.S., Schouten, S., Stüsser, I., Hofmann P. 2008. Rapid warming and salinity changes of Cretaceous surface waters in the subtropical North Atlantic, Geology, 36, 203-206. doi:10.1130/G24523A.1.

Waples, D.W., Machihara, T. 1990. Application of sterane and triterpane biomarkers in petroleum exploration. Bulletin of Canadian Petroleum Geology, 38(3), 357-380.

Waples, D.W., Machihara, T.M. 1991. Biomarkers for Geologists. AAPG Methods in Exploration Series No. 9. American Association of Petroleum Geologists, Tulsa, Oklahoma.

Weissert, H., Lini, A. 1991. Ice age interludes during the time of Cretaceous greenhouse climate. Controversies in Modern Geology. Academic Press, London, 173, 191.

Weissert, H., Lini, A., Föllmi, K. B., Kuhn, O. 1998. Correlation of Early Cretaceous carbon isotope stratigraphy and platform drowning events: a possible link?. Palaeogeography, Palaeoclimatology, Palaeoecology, 137(3-4), 189-203.

Zghal, I. 1994. Etude microbiostratigraphique du Crétacé inférieur de la Tunisie du centre ouest (régions de Kasserine-Sbeïtla et de Tadjerouine). Thèse de 3ème cycle Univ. Tunis II, 382.

Zghal, I., Ben Hadjali, N., Razgallah, S., Bismuth, H. 1997. Foraminiferes et Ostracodes de l'Aptien-Albien du Jebel Hameima (region de Tadjerouine, Tunisie): biostratigraphie, paleoecologie. Africa Geoscience Review, 4, 361-372.

Zouari, H., Turki, M.M., Delteil, J., Stephan, J.F. (1999). Tectonique transtensive de la paléomarge tunisienne au cours de l'Aptien-Campanien. Bulletin de la Société géologique de France, 170, 295-301. 


\section{FIGURE CAPTIONS}

Fig. 1 Locations of the studied outcrop sections on the present-day architecture of the Tunisian Atlas (A), comprising a faulted block and its compartments: the Tunisian Block (TB) is bounded by three mobile zones corresponding to three fault corridors (DZ, NSC and GNTC), each with its own structures, limiting the central block characterized by faults and widelyspaced folds (Rigane and Gourmelen, 2011), (B) Localities cited in the text on the schematic tectonic map of Tunisia (Rigane and Gourmelen, 2011).

Fig. 2 Sampled levels on the lithostratigraphic $\operatorname{logs}$ of the studied outcrop sections of the Fahdene Formation (Albian-Cenomanian) in central and northern Tunisia.

Fig. 3 Geochemical logs of TOC, PI and Tmax from Rock-Eval pyrolysis results. TOC, Total Organic Carbon (\%); PI, Production Index=S1/S1+S2; S1, free hydrocarbons (mg HCg${ }^{-1}$ Rock); S2, potential hydrocarbons (mg HC.g-1 Rock); Tmax, S2 maximum pyrolysis temperature $\left({ }^{\circ} \mathrm{C}\right)$; Fig. 4 Microscopic observations of representative samples of the Albian series from Koudiat Berkouchia (BRK) and Jebel Ghazouane (GZ) localities. Samples BRK11 and GZ12 show organic-rich wackestone laminations of thin dark layers and bright radiolarian-rich layers (dashed line). R: radiolarians; O: ostracods; Bit.: Bitumen; O: Ostracods; F: Foraminifera; Ta: Traces of algae.

Fig. 5 GC-MS chromatograms (Total Ion Current mode) of aliphatic fractions showing the nalkanes and acyclic isoprenoids for selected Fahdene Formation samples in central and northern Tunisia. Numbers refer to n-alkanes Carbon number long chain; $17, n-\mathrm{C}_{17} ; 18, n-\mathrm{C}_{18} ; \mathrm{Pr}$, pristane; Ph, phytane; Sq, Squalane.

Fig. 6 GC-MS chromatograms showing the distribution of terpanes $(\mathrm{m} / \mathrm{z} 191)$ and steranes $(\mathrm{m} / \mathrm{z}$ 217) of representative samples from the Fahdene Formation in central and northern Tunisia (for key see Table 3). 
Fig. 7 Location of the studied samples on a Carbonate contents $\left(\mathrm{CaCO}_{3}(\%)\right)$ vs. TOC crossplot expressing the abundance of bioturbations and the sea floor bottom water oxygenation.

Fig. 8 Fahdene Formation studied samples organic matter typing, thermal maturity and hydrocarbon potential on Rock-Eval pyrolysis diagrams: HI vs. OI (a), HI vs. Tmax (b), PP vs. TOC and Tmax versus PI. TOC, Total Organic Carbon (\% Rock); Tmax, S2 peak maximum pyrolysis temperature $\left({ }^{\circ} \mathrm{C}\right)$; HI, Hydrogen Index (mg HC. ${ }^{-1}$ TOC); OI, Oxygen Index (mg $\mathrm{CO}_{2} \mathrm{~g}^{-1}$ TOC); PP, Petroleum potential yield (S1+S2, mg HC.g ${ }^{-1}$ Rock); PI, Production Index $(\mathrm{S} 1 / \mathrm{S} 1+\mathrm{S} 2) ; \mathrm{S} 1$, free hydrocarbons (mg HC.g ${ }^{-1}$ Rock); S2, potential hydrocarbons (mg HC.g ${ }^{-1}$ Rock).

Fig. 9 Location of representative Fahdene Formation samples on a $\mathrm{Pr} / n-\mathrm{C}_{17}$ versus $\mathrm{Ph} / n-\mathrm{C}_{18}$ cross-plot. $\mathrm{Pr} / n-\mathrm{C}_{17}$ : pristane $/ n-\mathrm{C}_{17}$ peak height ratio; $\mathrm{Ph} / n-\mathrm{C}_{18}$ : phytane/ $n$ - $\mathrm{C}_{18}$ peak height ratio. Fig. 10 (A) Palaeogeographic map at $\sim 113 \mathrm{Ma}$ (modified after Huber and Leckie (2011) and Sabatino et al., 2015) showing the location of Tunisia (TN) and the Vocontian Basin (VB). (B) Albian Oceanic Anoxic Events (OAE) records on a synthetic model of the deposition of the Lower Fahdene Formation in the studied zone in relationship with oxygen minimum zone (OMZ), upwelling, primary organic productivity (POP) and structural setting.

\section{TABLE CAPTIONS}

Table 1 Carbonate contents and Rock-Eval 6 (Espitalié et al., 1985; Lafargue et al., 1998; Behar et al., 2001) analysis of Albian Fahdene Formation samples from central and northern Tunisia. Table 2 Bulk data for solvent extraction and chromatographic characterization of Fahdene Formation selected samples.

Table 3 Peak assignment for steranes $(\mathrm{m} / \mathrm{z} 217)$ and triterpanes $(\mathrm{m} / \mathrm{z} 191)$ in the GC-MS chromatograms of figure 6.

Table 4 Terpane (m/z 191) and sterane (m/z 217) results from GC-MS analysis of the Albian $\mathrm{OM}$ in central and northern Tunisia. 
Figure 1 


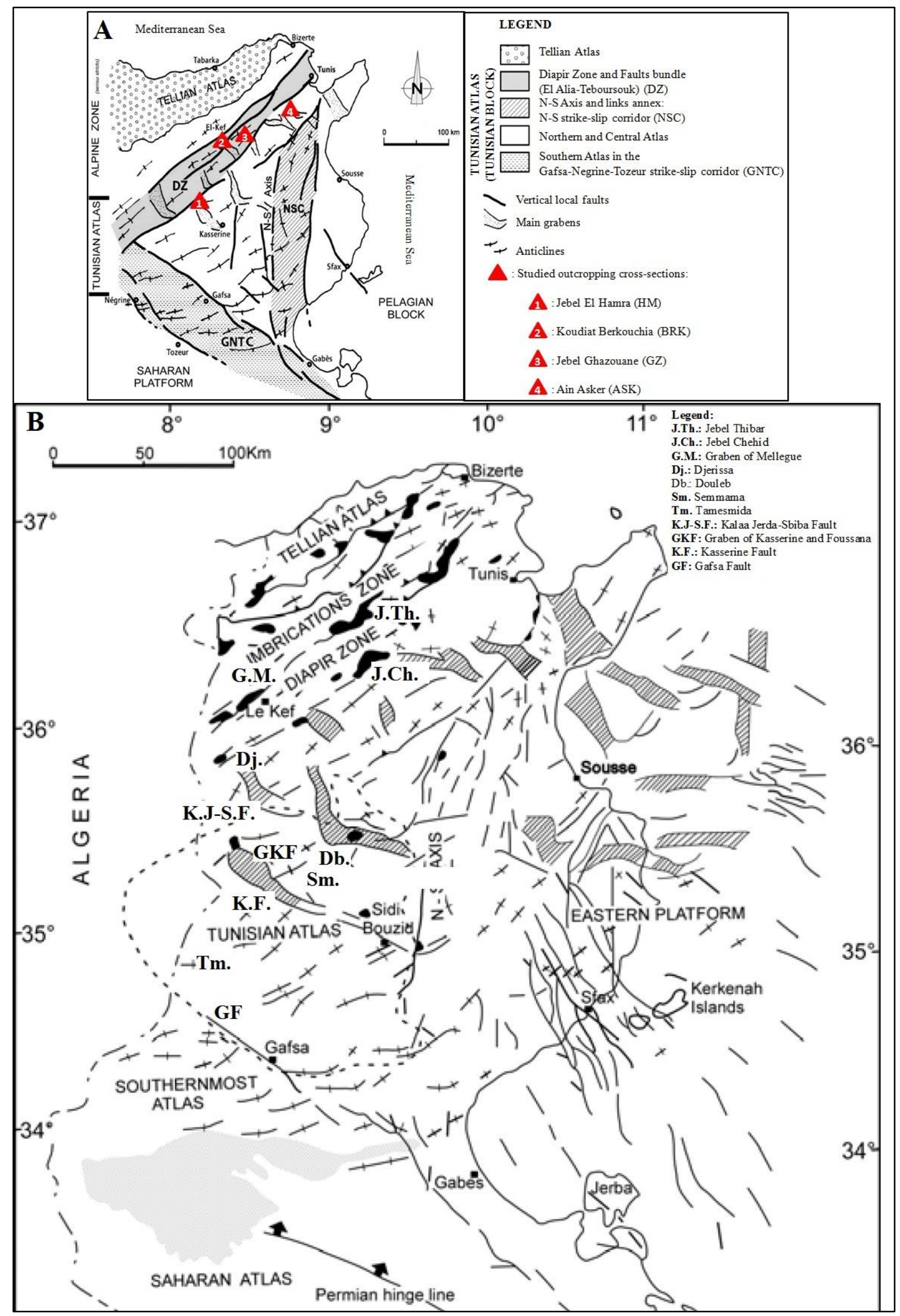

Figure 2 


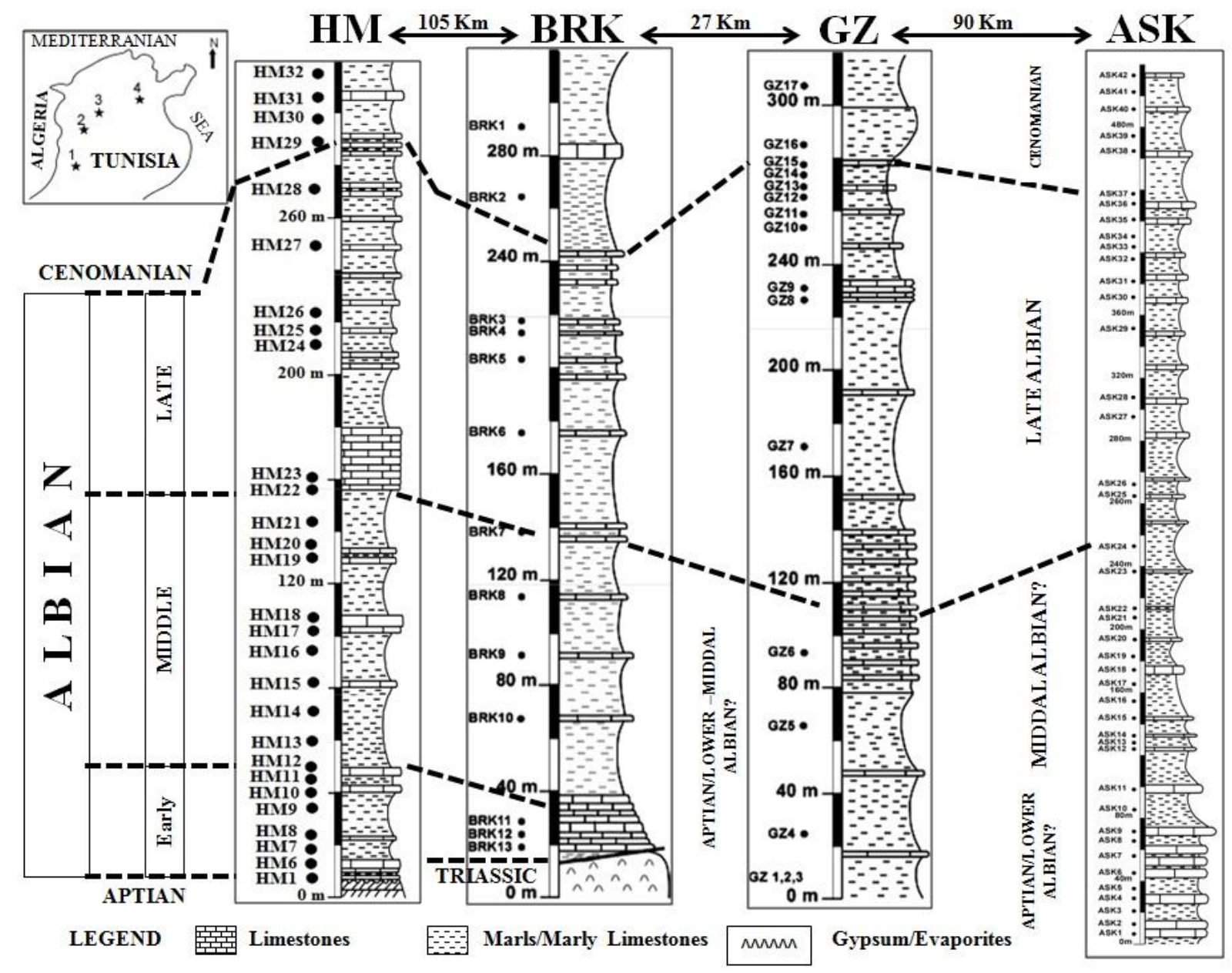

Figure 3 

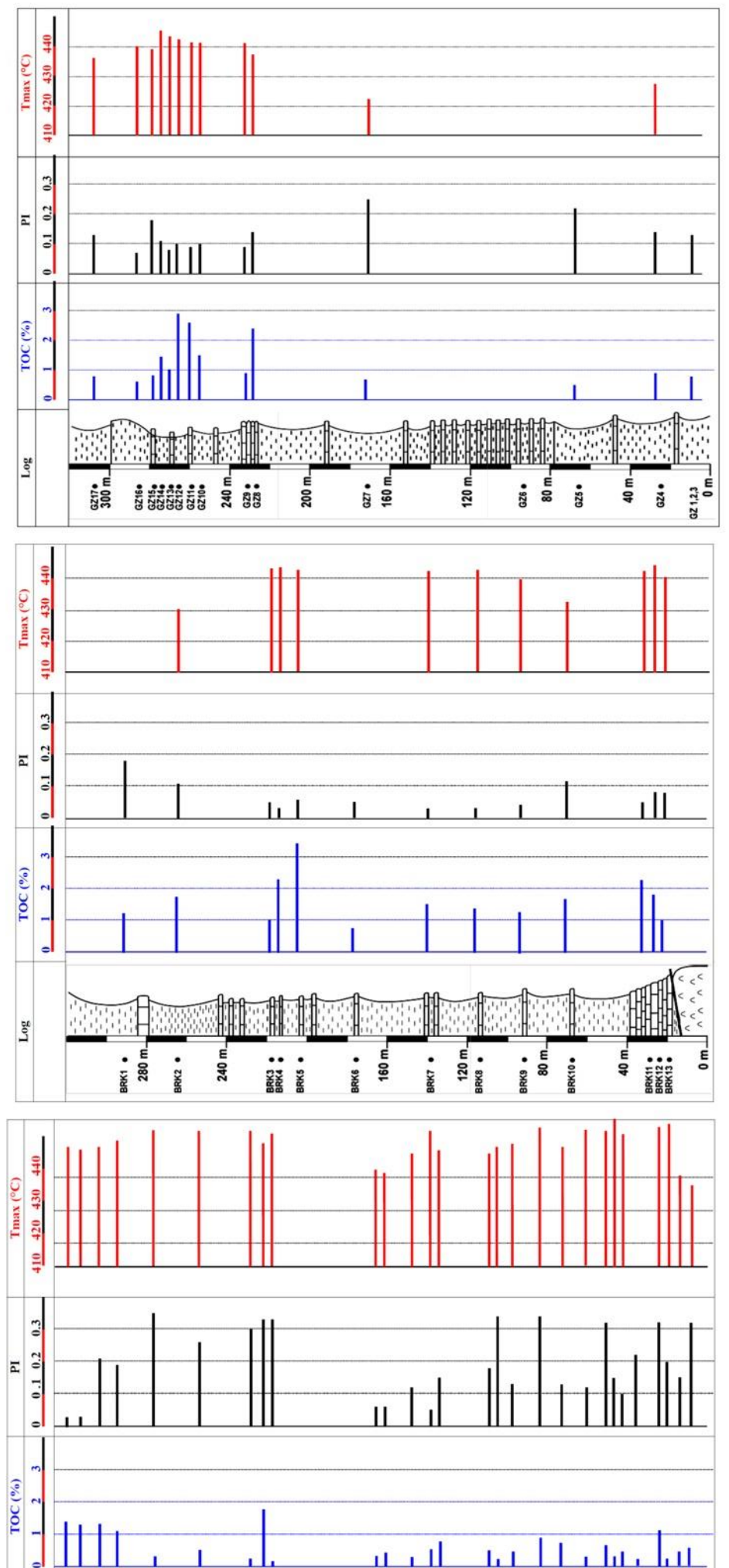
Figure 4 

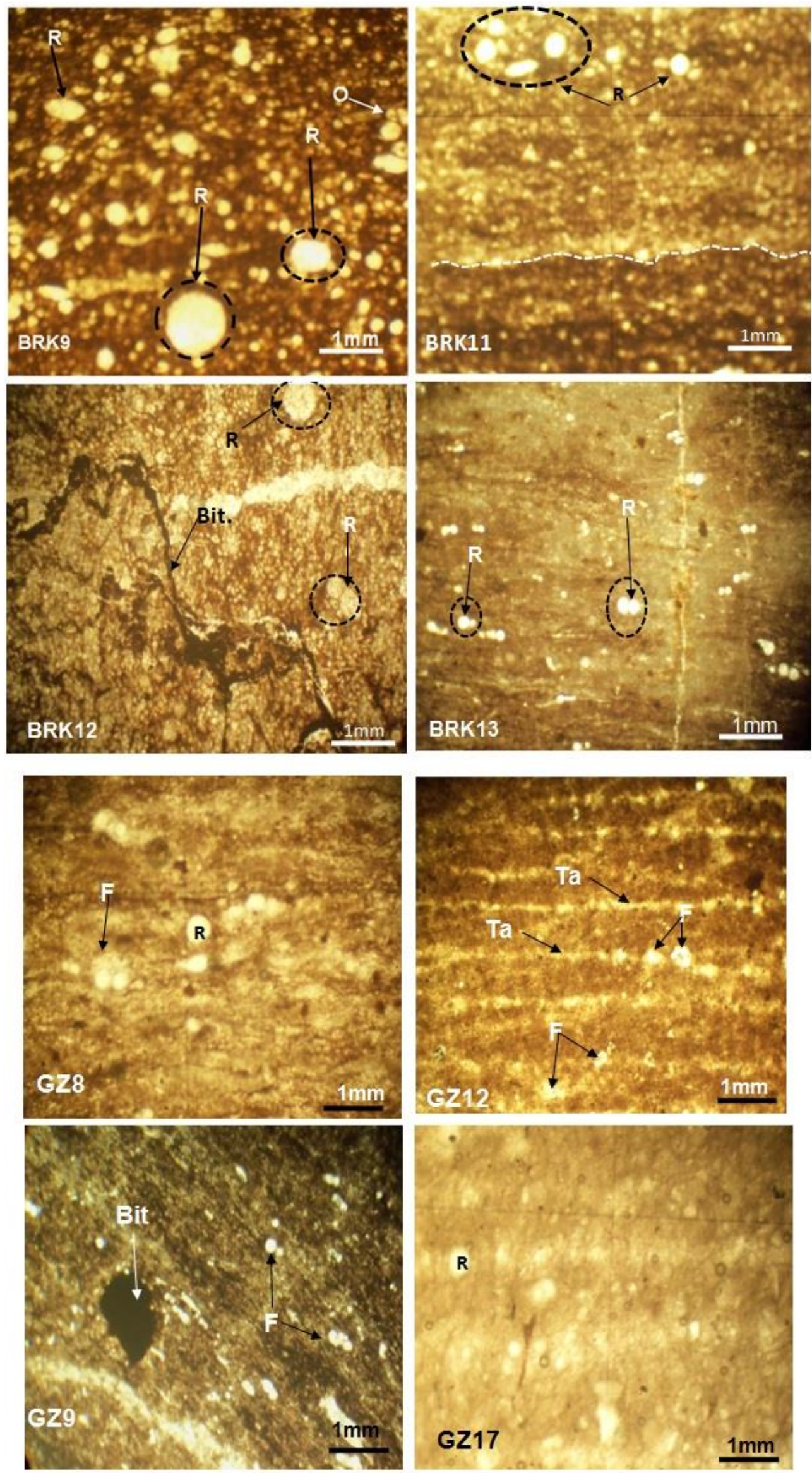

Figure 5 

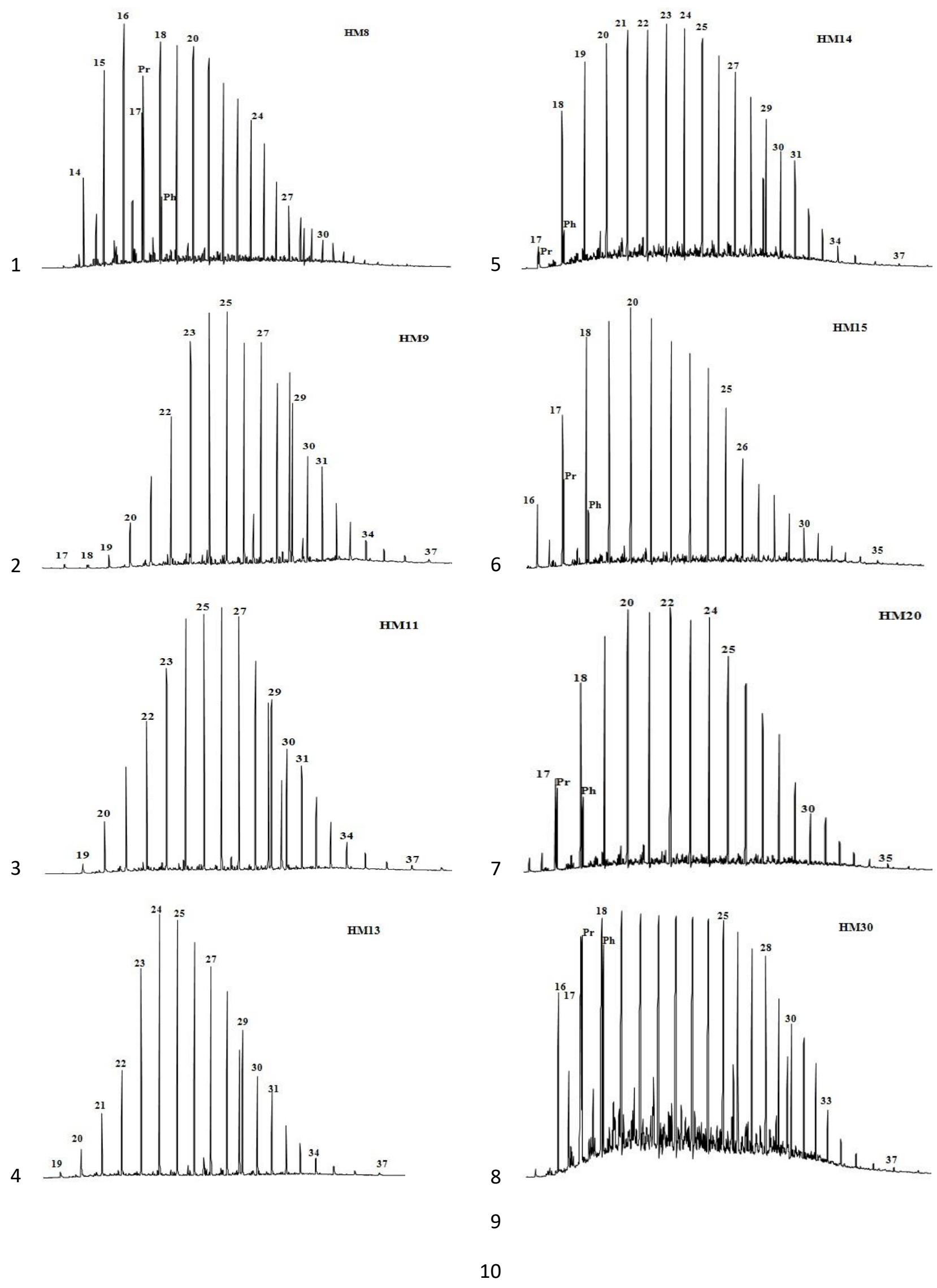

11 Figure 5 continued 

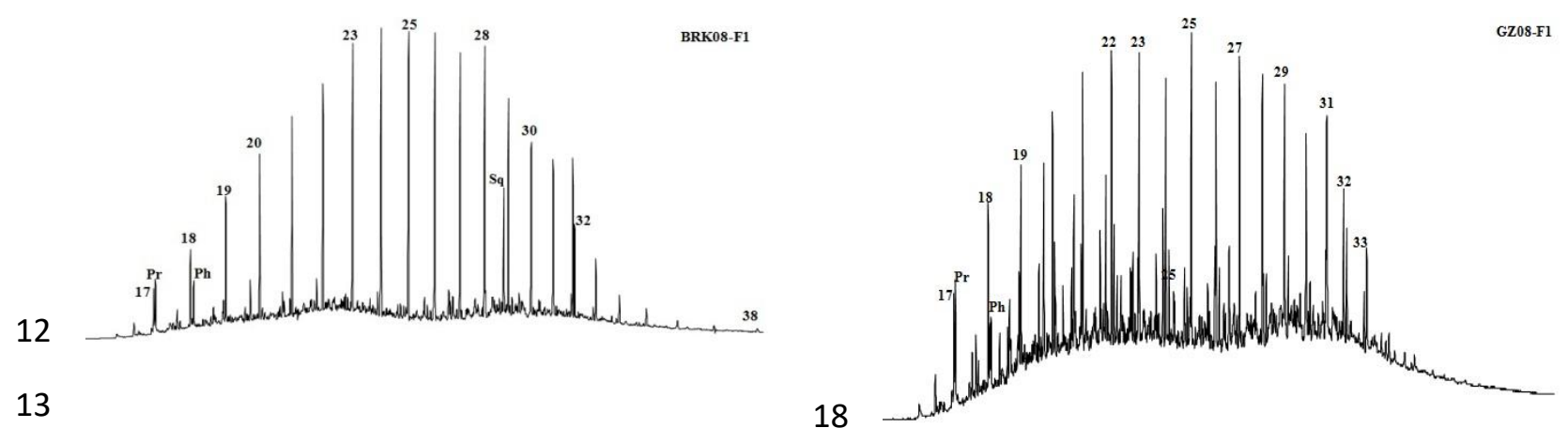

13
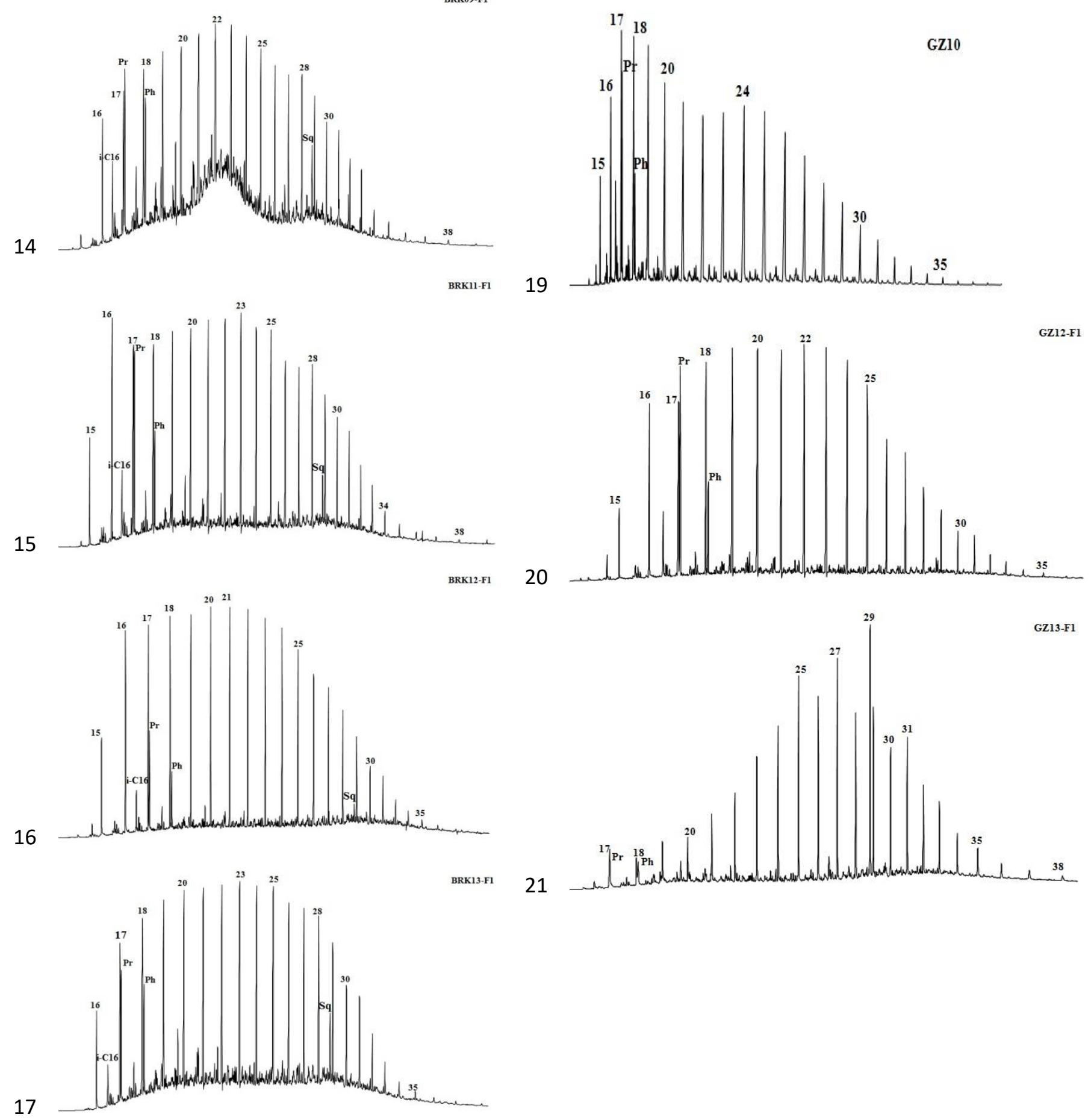

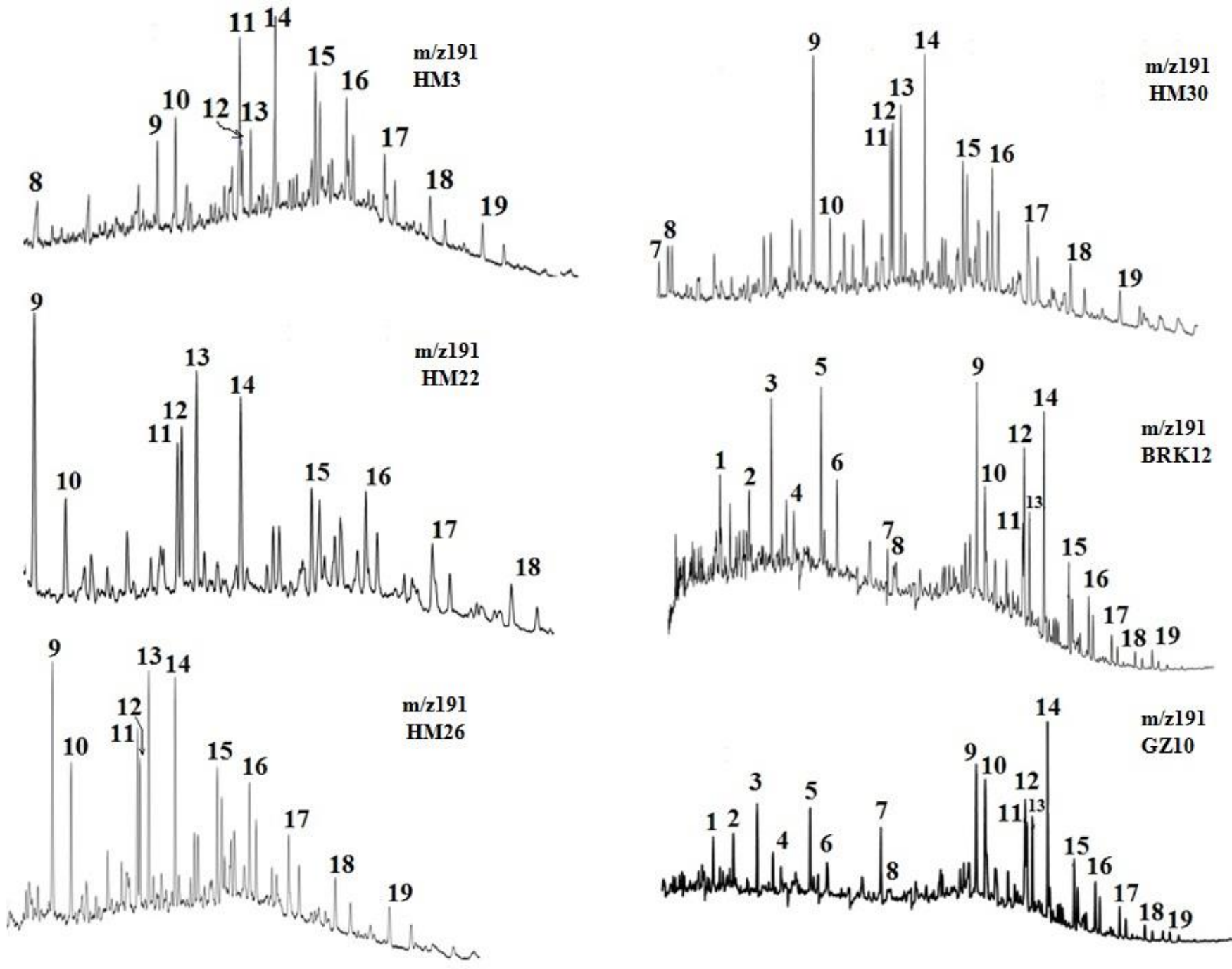
34

35

36
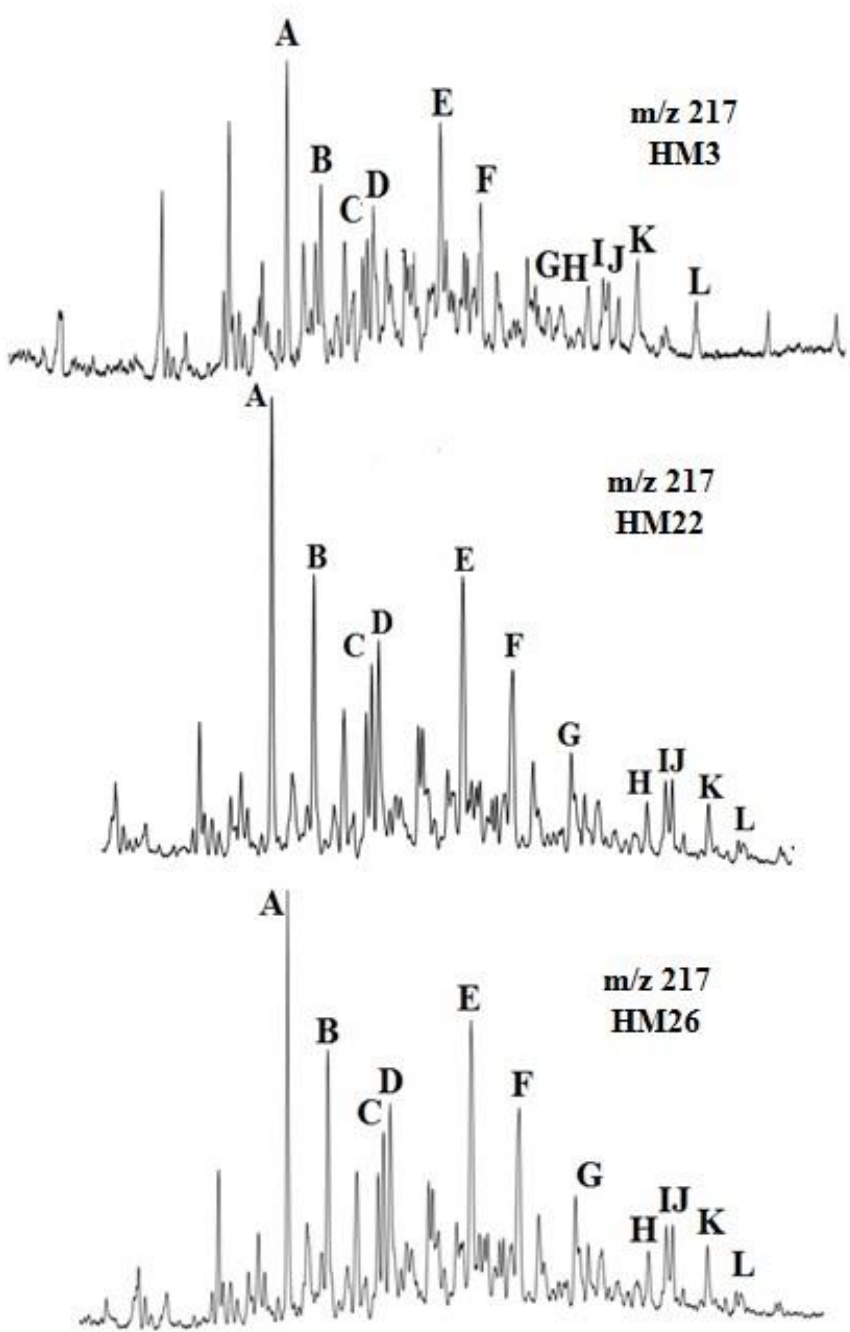
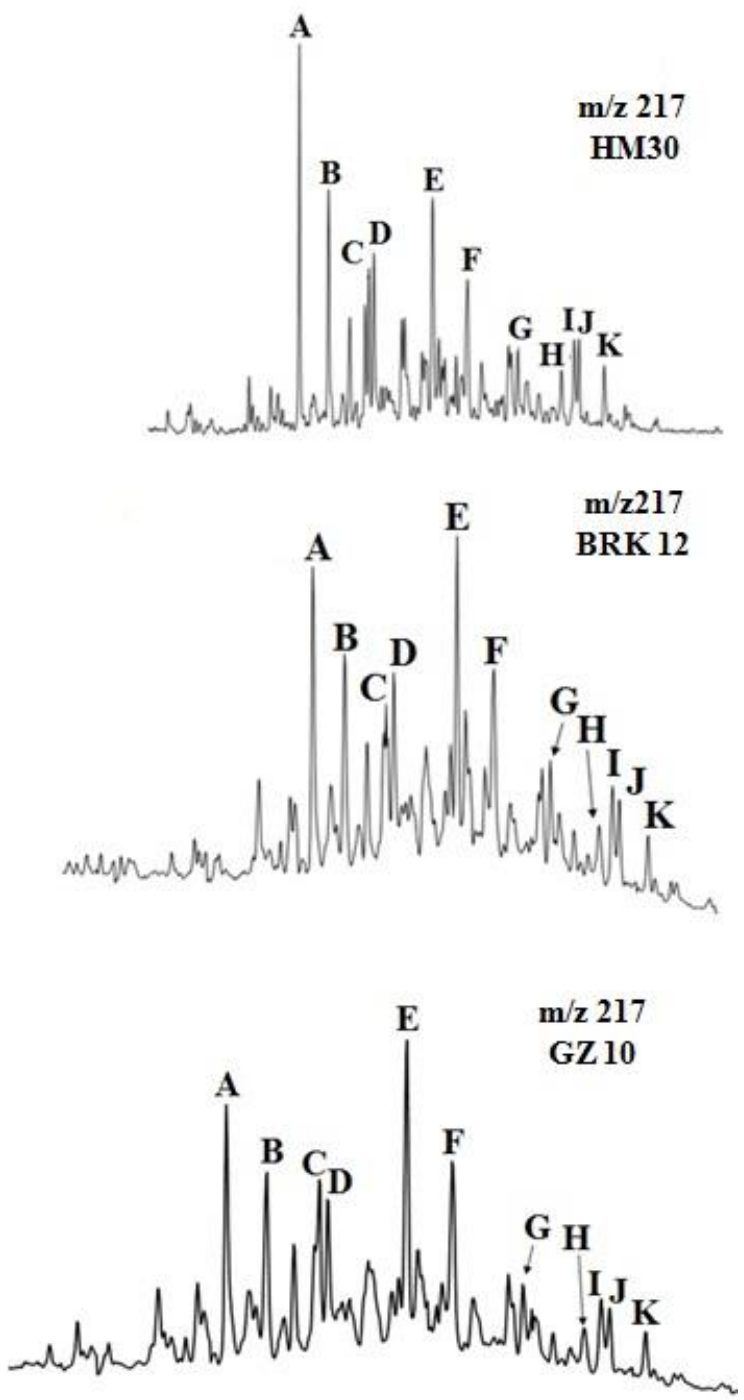


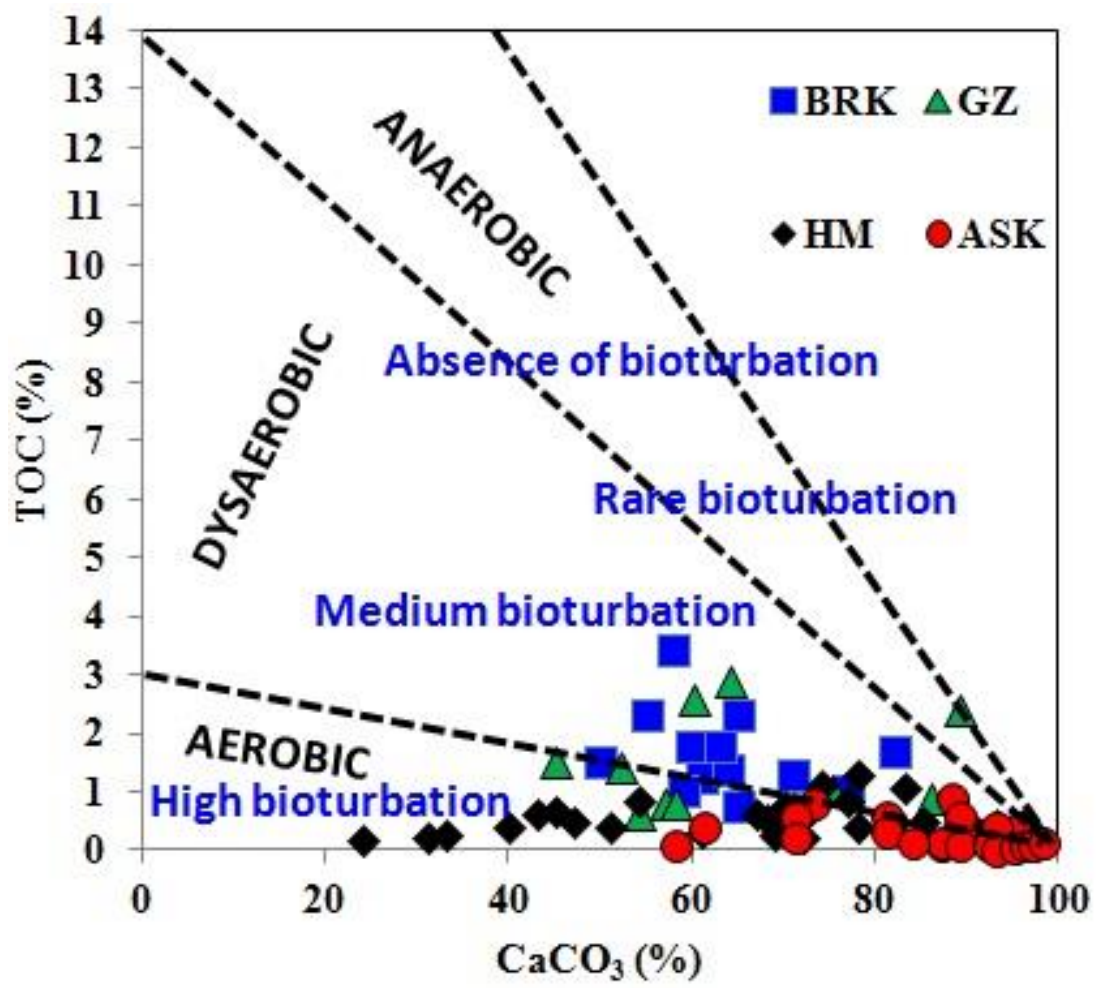




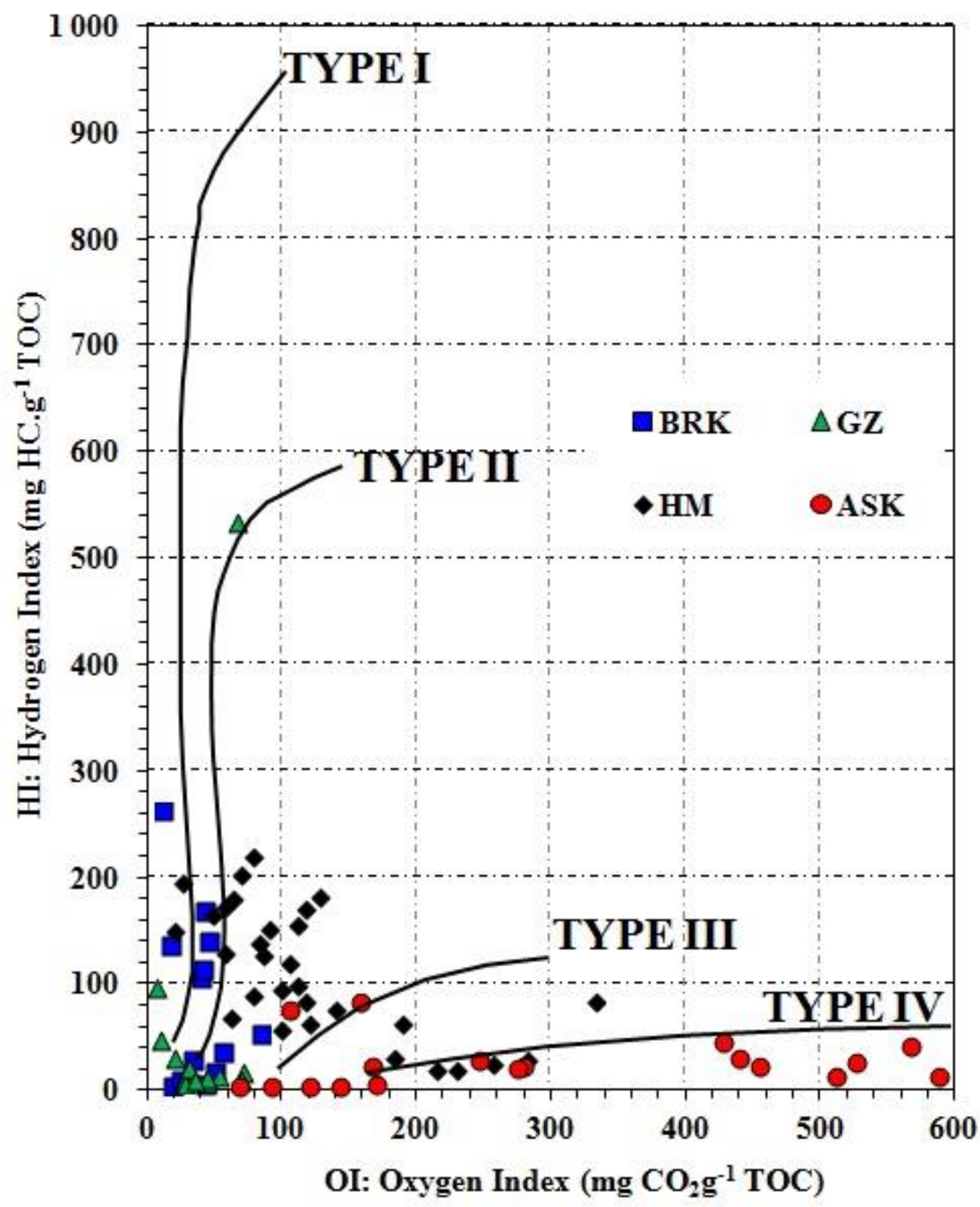




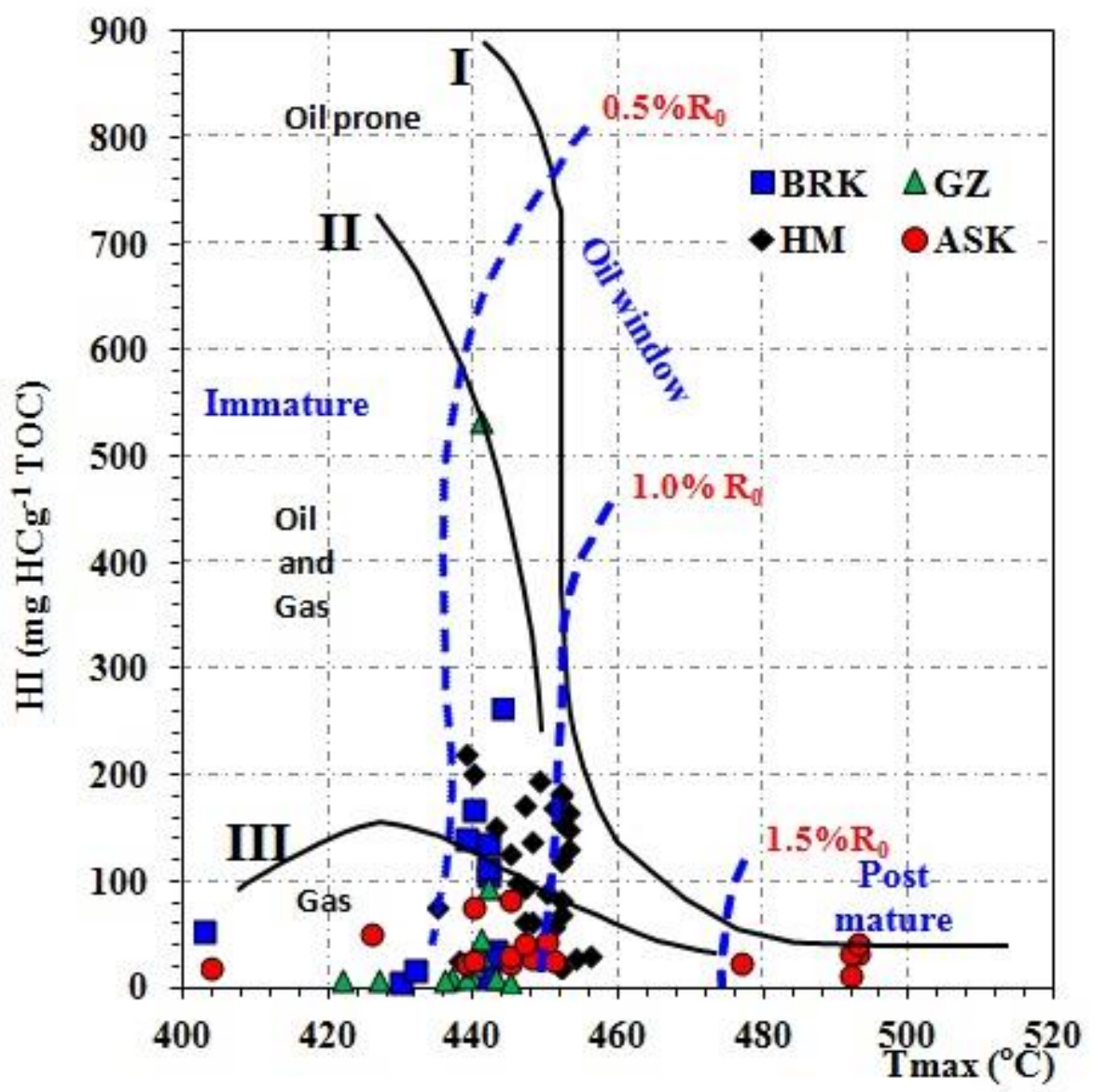


82

Figure 8c

83

84

85

86

87

88

89

90

91

92

93

94

\section{QUALITATIVE ASSESSMENT OF ORGANIC CONTENT}

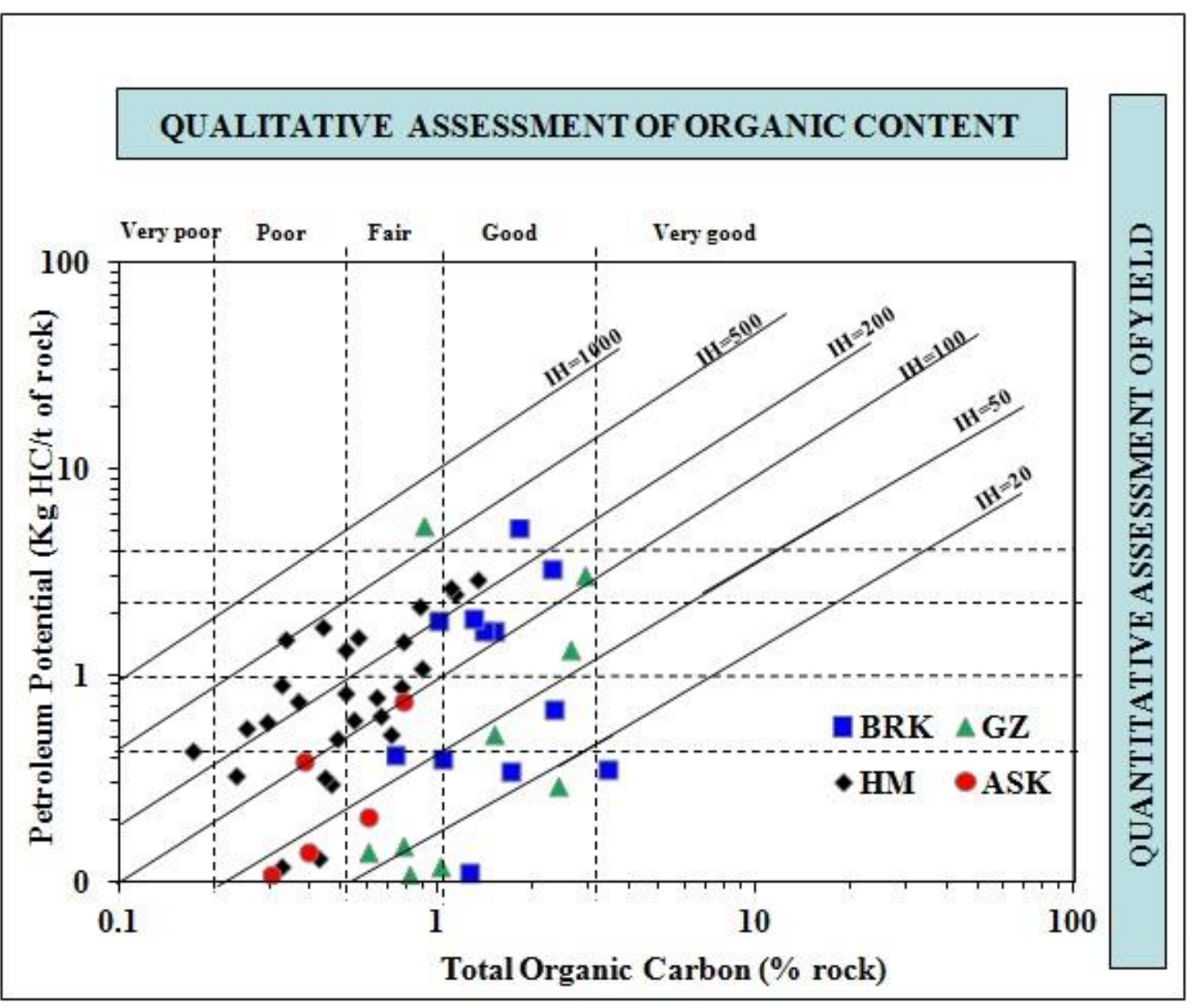




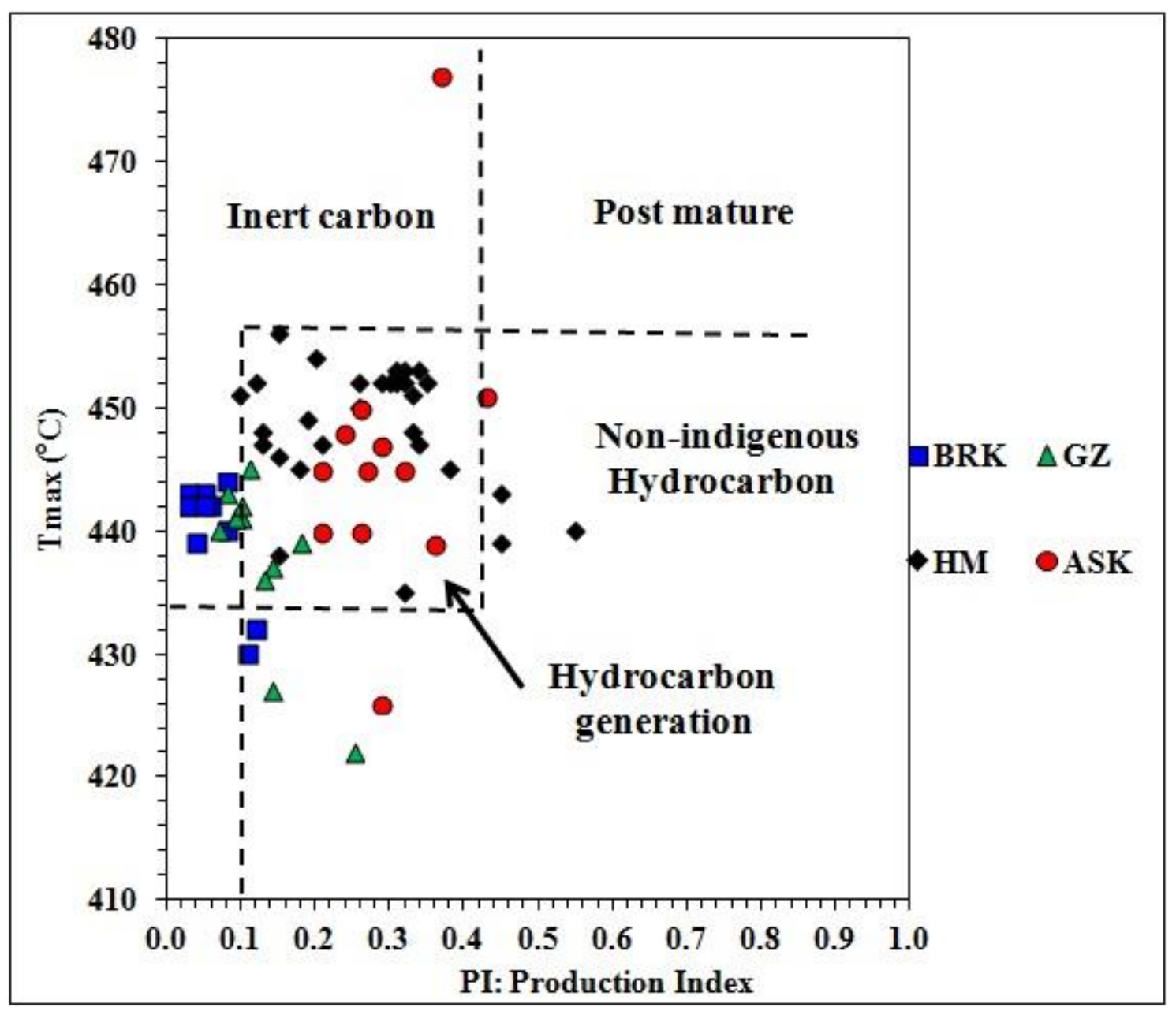

100 
Figure 9

109

110

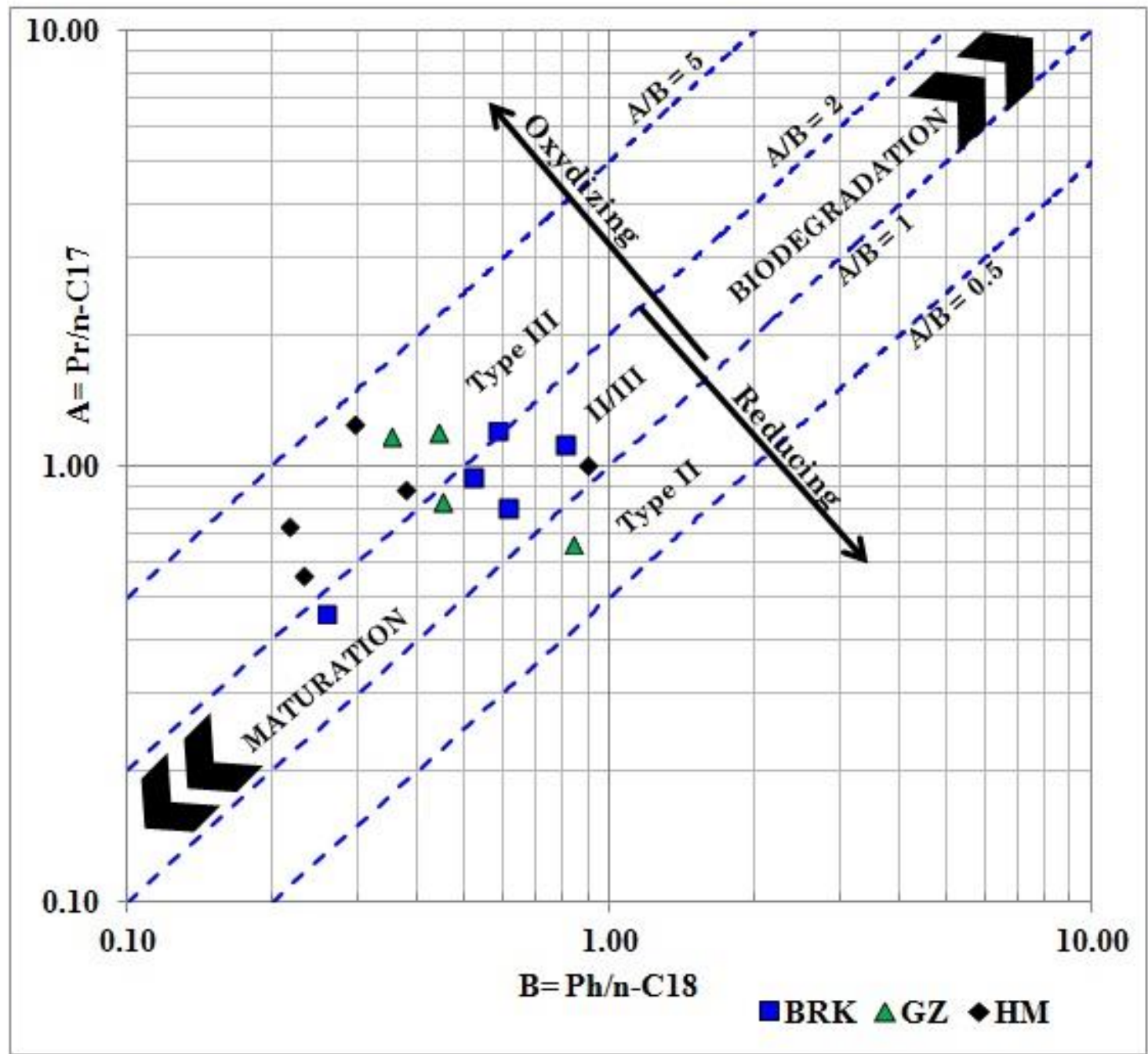

112

113

114

115

116

117 


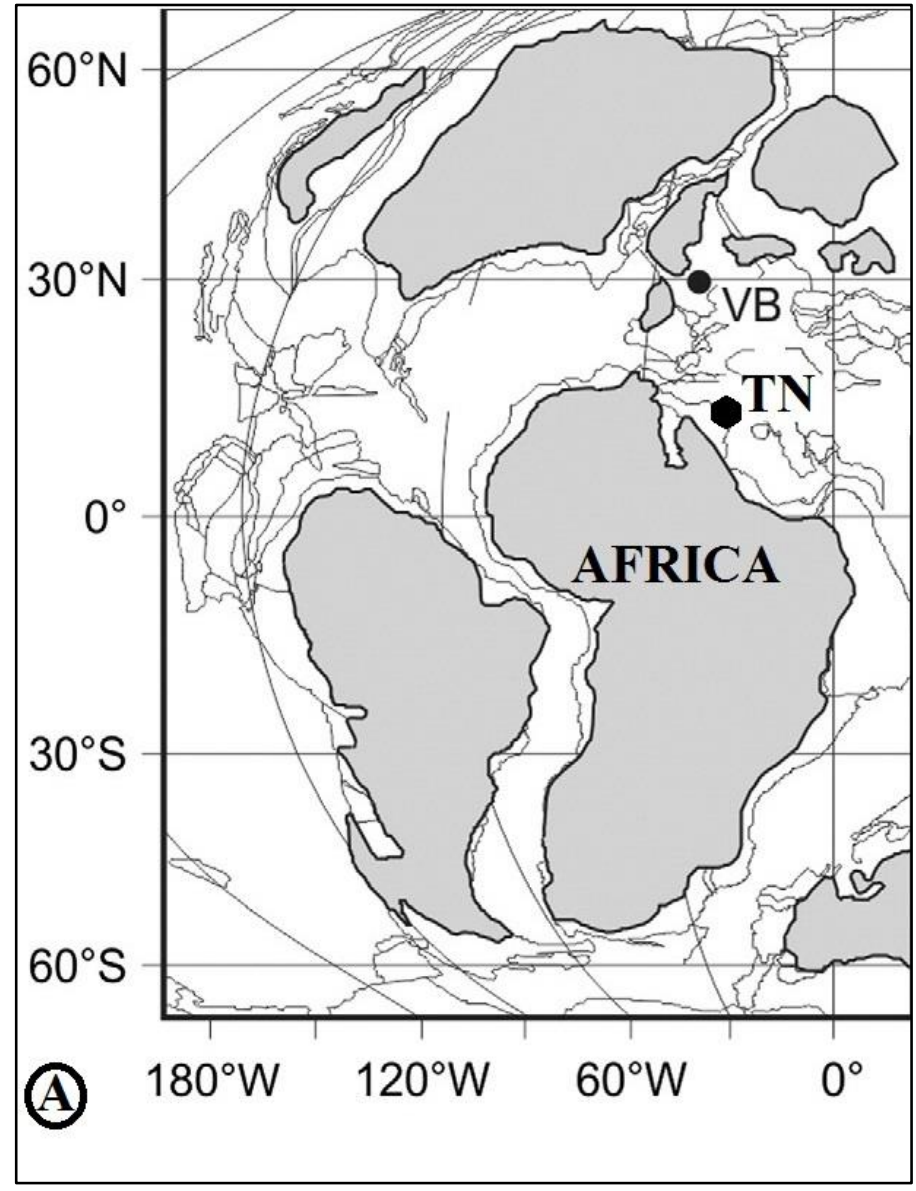

(S)
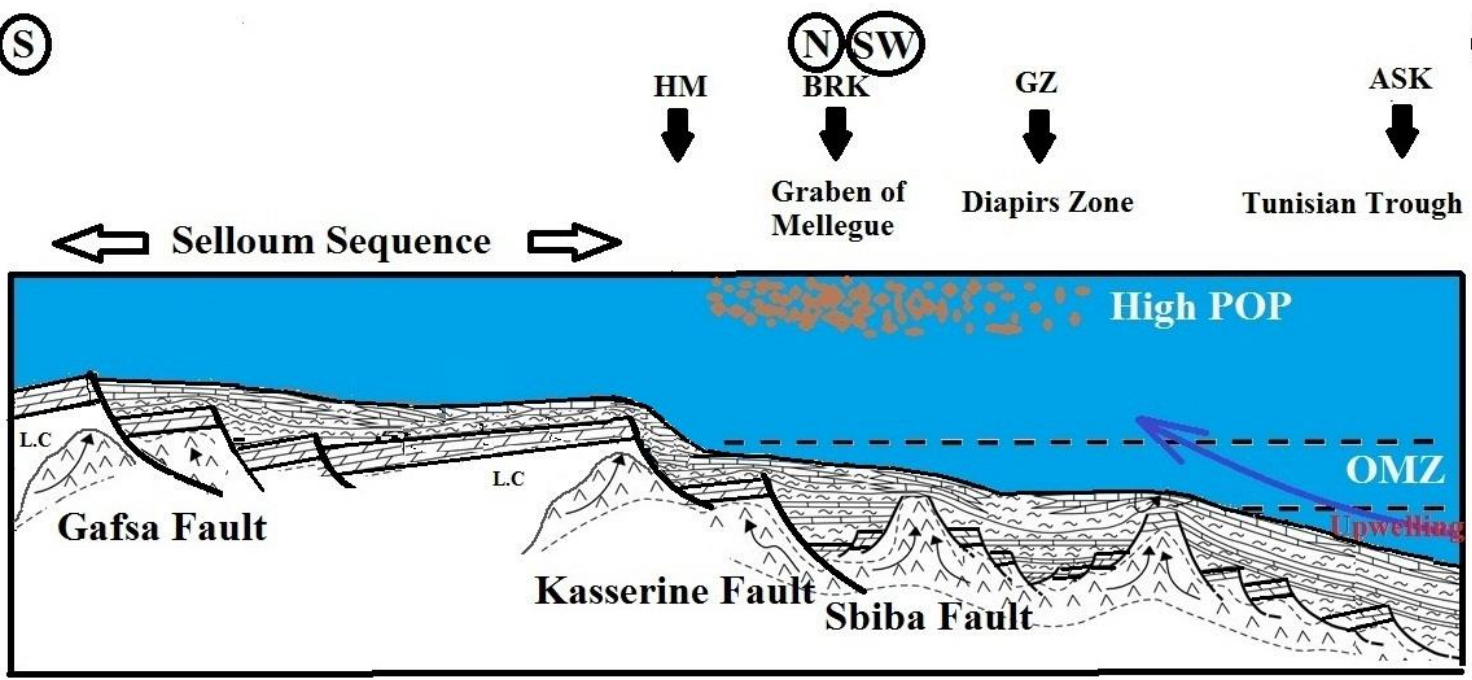

\section{LEGEND}

L.C: Lower Cretaceous
series, Ante-Aptian




\begin{tabular}{|c|c|c|c|c|c|c|c|c|c|c|}
\hline Samples & $\mathrm{CaCO}_{3}(\%)$ & TOC $^{\mathbf{a}}$ & $\overline{\text { S1 }^{\mathbf{b}}}$ & $\mathbf{S 2}^{\mathbf{c}}$ & $\mathbf{S 3}^{\mathrm{d}}$ & $\overline{\mathbf{P P}^{\mathrm{e}}}$ & $\mathbf{P I}^{\mathbf{f}}$ & $\overline{\mathrm{HI}^{\mathrm{g}}}$ & $\mathrm{OI}^{\mathrm{h}}$ & Tmax $^{\mathrm{i}}$ \\
\hline BRK1 & 61 & 1.25 & 0.02 & 0.09 & 0.52 & 0.11 & 0.18 & 7 & 42 & 361 \\
\hline BRK2 & 60 & 1.77 & 0.01 & 0.08 & 0.33 & 0.09 & 0.11 & 5 & 19 & 430 \\
\hline BRK3 & 59 & 1.04 & 0.02 & 0.37 & 0.58 & 0.39 & 0.05 & 36 & 56 & 443 \\
\hline BRK4 & 55 & 2.32 & 0.02 & 0.67 & 0.8 & 0.69 & 0.03 & 29 & 34 & 443 \\
\hline BRK5 & 58 & 3.43 & 0.02 & 0.33 & 0.85 & 0.35 & 0.06 & 10 & 25 & 442 \\
\hline BRK6 & 65 & 0.74 & 0.02 & 0.39 & 0.62 & 0.41 & 0.05 & 53 & 84 & 403 \\
\hline BRK7 & 50 & 1.5 & 0.05 & 1.59 & 0.58 & 1.64 & 0.03 & 106 & 39 & 442 \\
\hline BRK8 & 64 & 1.4 & 0.05 & 1.59 & 0.57 & 1.64 & 0.03 & 114 & 41 & 442 \\
\hline BRK9 & 71 & 1.3 & 0.07 & 1.82 & 0.6 & 1.89 & 0.04 & 140 & 46 & 439 \\
\hline BRK10 & 82 & 1.7 & 0.04 & 0.3 & 0.85 & 0.34 & 0.12 & 18 & 50 & 432 \\
\hline BRK11 & 65 & 2.3 & 0.16 & 3.14 & 0.39 & 3.3 & 0.05 & 137 & 17 & 442 \\
\hline BRK12 & 63 & 1.8 & 0.39 & 4.74 & 0.21 & 5.13 & 0.08 & 263 & 12 & 444 \\
\hline BRK13 & 77 & 1.01 & 0.14 & 1.71 & 0.42 & 1.85 & 0.08 & 169 & 42 & 440 \\
\hline GZ3 & 1,3 & 0.78 & 0.02 & 0.13 & 0.56 & 0.15 & 0.13 & 17 & 72 & 390 \\
\hline GZ4 & 1,4 & 0.9 & 0.01 & 0.06 & 0.4 & 0.07 & 0.14 & 7 & 44 & 427 \\
\hline GZ5 & 0,93 & 0.5 & 0.02 & 0.07 & 0.27 & 0.09 & 0.22 & 14 & 54 & 353 \\
\hline GZ7 & 3,27 & 0.68 & 0.02 & 0.06 & 0.48 & 0.08 & 0.25 & 9 & 70 & 422 \\
\hline GZ8 & 89 & 2.4 & 0.04 & 0.25 & 0.64 & 0.29 & 0.14 & 10 & 27 & 437 \\
\hline GZ9 & 86 & 0.9 & 0.49 & 4.8 & 0.6 & 5.29 & 0.09 & 533 & 67 & 441 \\
\hline GZ10 & 45 & 1.5 & 0.05 & 0.47 & 0.32 & 0.52 & 0.1 & 31 & 21 & 441 \\
\hline GZ11 & 60 & 2.6 & 0.12 & 1.22 & 0.26 & 1.34 & 0.09 & 47 & 10 & 441 \\
\hline GZ12 & 64 & 2.9 & 0.31 & 2.79 & 0.23 & 3.1 & 0.1 & 96 & 8 & 442 \\
\hline GZ13 & 75 & 1.02 & 0.01 & 0.11 & 0.29 & 0.12 & 0.08 & 11 & 28 & 443 \\
\hline GZ14 & 52 & 1.45 & 0.01 & 0.08 & 0.4 & 0.09 & 0.11 & 6 & 28 & 445 \\
\hline GZ15 & 57 & 0.82 & 0.02 & 0.09 & 0.37 & 0.11 & 0.18 & 11 & 45 & 439 \\
\hline GZ16 & 54 & 0.61 & 0.01 & 0.13 & 0.19 & 0.14 & 0.07 & 21 & 31 & 440 \\
\hline GZ17 & 58 & 0.79 & 0.01 & 0.07 & 0.28 & 0.08 & 0.13 & 9 & 35 & 436 \\
\hline HM 1 & 47 & 0.54 & 0.19 & 0.42 & 0.76 & 0.61 & 0.32 & 77 & 140 & 435 \\
\hline HM 2 & 68 & 0.56 & 0.69 & 0.86 & 0.51 & 1.55 & 0.45 & 153 & 91 & 443 \\
\hline HM 3 & 43 & 0.66 & 0.18 & 0.46 & 0.41 & 0.64 & 0.29 & 70 & 62 & 452 \\
\hline HM 4 & 70 & 0.77 & 0.46 & 1.01 & 0.45 & 1.47 & 0.31 & 131 & 58 & 453 \\
\hline HM 5 & 54 & 0.89 & 0.28 & 0.81 & 0.69 & 1.09 & 0.26 & 91 & 78 & 450 \\
\hline HM 6 & 51 & 0.42 & 0.02 & 0.11 & 1.08 & 0.13 & 0.15 & 26 & 257 & 438 \\
\hline HM 7 & 31 & 0.24 & 0.02 & 0.07 & 0.68 & 0.09 & 0.2 & 29 & 283 & 454 \\
\hline HM 8 & 74 & 1.12 & 0.79 & 1.69 & 0.23 & 2.48 & 0.32 & 151 & 21 & 453 \\
\hline HM 9 & 24 & 0.19 & 0.01 & 0.04 & 0.41 & 0.05 & 0.22 & 21 & 215 & 585 \\
\hline HM 10 & 96 & 0.46 & 0.03 & 0.27 & 0.46 & 0.3 & 0.1 & 59 & 100 & 451 \\
\hline HM 11 & 61 & 0.32 & 0.02 & 0.1 & 0.59 & 0.12 & 0.15 & 31 & 184 & 456 \\
\hline HM 12 & 67 & 0.64 & 0.25 & 0.54 & 2.13 & 0.79 & 0.32 & 84 & 333 & 452 \\
\hline HM 13 & 33 & 0.3 & 0.01 & 0.06 & 0.69 & 0.07 & 0.12 & 20 & 230 & 452 \\
\hline HM 14 & 45 & 0.71 & 0.07 & 0.45 & 0.86 & 0.52 & 0.13 & 63 & 121 & 447 \\
\hline HM 15 & 77 & 0.87 & 0.74 & 1.45 & 0.42 & 2.19 & 0.34 & 167 & 48 & 453 \\
\hline
\end{tabular}




\begin{tabular}{|c|c|c|c|c|c|c|c|c|c|c|}
\hline HM 16 & 40 & 0.44 & 0.04 & 0.28 & 0.83 & 0.32 & 0.13 & 64 & 189 & 448 \\
\hline HM 17 & 95 & 0.23 & 0.11 & 0.22 & 0.23 & 0.33 & 0.34 & 96 & 100 & 447 \\
\hline HM 18 & 93 & 0.48 & 0.09 & 0.41 & 0.56 & 0.5 & 0.18 & 85 & 117 & 445 \\
\hline HM 19 & 73 & 0.76 & 0.13 & 0.75 & 0.85 & 0.88 & 0.15 & 99 & 112 & 446 \\
\hline HM 20 & 82 & 0.51 & 0.42 & 0.93 & 0.32 & 1.35 & 0.31 & 182 & 63 & 452 \\
\hline HM 21 & 69 & 0.29 & 0.23 & 0.37 & 0.25 & 0.6 & 0.38 & 128 & 86 & 445 \\
\hline HM 22 & 78 & 0.43 & 0.76 & 0.95 & 0.34 & 1.71 & 0.45 & 220 & 79 & 439 \\
\hline HM 23 & 91 & 0.33 & 0.83 & 0.67 & 0.2 & 1.5 & 0.55 & 203 & 70 & 440 \\
\hline HM 24 & 92 & 0.17 & 0.14 & 0.29 & 0.2 & 0.43 & 0.33 & 171 & 118 & 451 \\
\hline HM 25 & 97 & 0.36 & 0.25 & 0.5 & 0.3 & 0.75 & 0.33 & 139 & 83 & 448 \\
\hline HM 26 & 72 & 0.25 & 0.17 & 0.39 & 0.28 & 0.56 & 0.3 & 156 & 112 & 452 \\
\hline HM 27 & 85 & 0.51 & 0.21 & 0.61 & 0.54 & 0.82 & 0.26 & 120 & 106 & 452 \\
\hline HM 28 & 71 & 0.32 & 0.31 & 0.59 & 0.41 & 0.9 & 0.35 & 184 & 128 & 452 \\
\hline HM 29 & 83 & 1.1 & 0.52 & 2.17 & 0.29 & 2.69 & 0.19 & 197 & 26 & 449 \\
\hline HM 30 & 78 & 1.32 & 0.6 & 2.3 & 0.77 & 2.9 & 0.21 & 174 & 58 & 447 \\
\hline ASK1 & 89 & 0.3 & 0.04 & 0.07 & 0.84 & 0.11 & 0.36 & 23 & 280 & 439 \\
\hline ASK3 & 81 & 0.58 & 0.05 & 0.02 & 0.7 & 0.07 & 0.71 & 3 & 121 & 299 \\
\hline ASK4 & 88 & 0.2 & 0.03 & 0.04 & 0.55 & 0.07 & 0.45 & 20 & 275 & 404 \\
\hline ASK5 & 73 & 0.78 & 0.16 & 0.59 & 0.82 & 0.75 & 0.21 & 76 & 105 & 440 \\
\hline ASK6 & 87 & 0.11 & 0.01 & 0.03 & 0.58 & 0.04 & 0.26 & 27 & 527 & 440 \\
\hline ASK7 & 71 & 0.6 & 0.07 & 0.14 & 1 & 0.21 & 0.32 & 23 & 167 & 445 \\
\hline ASK8 & 81 & 0.33 & 0.05 & 0.02 & 0.56 & 0.07 & 0.69 & 6 & 170 & 310 \\
\hline ASK11 & 95 & 0.37 & 0.04 & 0.01 & 0.53 & 0.05 & 0.81 & 3 & 143 & 295 \\
\hline ASK12 & 97 & 0.08 & 0.02 & 0.01 & 0.47 & 0.03 & 0.75 & 12 & 588 & 292 \\
\hline ASK14 & 93 & 0.38 & 0.08 & 0.31 & 0.6 & 0.39 & 0.21 & 82 & 158 & 445 \\
\hline ASK17 & 61 & 0.39 & 0.03 & 0.11 & 0.96 & 0.14 & 0.24 & 28 & 246 & 448 \\
\hline ASK18 & 87 & 0.13 & 0.02 & 0.03 & 0.59 & 0.05 & 0.37 & 23 & 454 & 477 \\
\hline ASK20 & 89 & 0.07 & 0.01 & 0.01 & 0.58 & 0.02 & 0.51 & 14 & 829 & 317 \\
\hline ASK22 & 88 & 0.89 & 0.05 & 0.03 & 0.61 & 0.08 & 0.64 & 3 & 69 & 295 \\
\hline ASK23 & 89 & 0.6 & 0.04 & 0.02 & 0.55 & 0.06 & 0.67 & 3 & 92 & 290 \\
\hline ASK24 & 58 & 0.11 & 0.02 & 0.03 & 0.67 & 0.05 & 0.43 & 27 & 609 & 451 \\
\hline ASK25 & 93 & 0.03 & 0.01 & 0.01 & 0.3 & 0.02 & 0.48 & 33 & 1000 & 493 \\
\hline ASK27 & 92 & 0.11 & 0.02 & 0.05 & 0.47 & 0.07 & 0.26 & 45 & 427 & 450 \\
\hline ASK29 & 71 & 0.2 & 0.02 & 0.06 & 0.88 & 0.08 & 0.27 & 30 & 440 & 445 \\
\hline ASK31 & 93 & 0.02 & 0.01 & 0.01 & 0.32 & 0.02 & 0.5 & 50 & 1600 & 287 \\
\hline ASK32 & 95 & 0.03 & 0.01 & 0.01 & 0.36 & 0.02 & 0.32 & 33 & 1200 & 492 \\
\hline ASK34 & 96 & 0.08 & 0.01 & 0.01 & 0.41 & 0.02 & 0.34 & 12 & 512 & 492 \\
\hline ASK36 & 97 & 0.07 & 0.01 & 0.03 & 0.44 & 0.04 & 0.28 & 43 & 629 & 493 \\
\hline ASK38 & 84 & 0.12 & 0.02 & 0.05 & 0.68 & 0.07 & 0.29 & 42 & 567 & 447 \\
\hline ASK42 & 98 & 0.12 & 0.02 & 0.06 & 1.62 & 0.08 & 0.29 & 50 & 1350 & 426 \\
\hline
\end{tabular}




\begin{tabular}{|c|c|c|c|c|c|c|c|c|c|}
\hline \multirow{2}{*}{ Name } & \multirow{2}{*}{$\begin{array}{c}\text { TOC } \\
(\% \mathrm{R})^{\mathrm{a}}\end{array}$} & \multirow{2}{*}{$\begin{array}{c}\text { EOM } \\
(\% o R)^{b}\end{array}$} & \multirow{2}{*}{$\begin{array}{c}\text { EOM } \\
(\% \text { TOC })\end{array}$} & \multicolumn{3}{|c|}{ EOM Composition (\%) } & \multicolumn{3}{|c|}{ GC of SHCs } \\
\hline & & & & $\mathrm{NSO}^{\mathrm{c}}$ & $\mathrm{SHCs}^{\mathrm{d}}$ & $\mathrm{AHCs}^{\mathrm{e}}$ & $\mathrm{Pr} / \mathrm{Ph}^{\mathrm{f}}$ & $\operatorname{Pr} / n-\mathrm{C}_{17} \mathrm{~g}$ & $\mathrm{Ph} / n-\mathrm{C}_{18}$ \\
\hline BRK8 & 1.4 & $\mathrm{Nd}^{\mathrm{i}}$ & $\mathrm{Nd}$ & $\mathrm{Nd}$ & $\mathrm{Nd}$ & $\mathrm{Nd}$ & 1.13 & 1.21 & 1.13 \\
\hline BRK9 & 1.3 & $\mathrm{Nd}$ & $\mathrm{Nd}$ & $\mathrm{Nd}$ & $\mathrm{Nd}$ & $\mathrm{Nd}$ & 1.29 & 1.14 & 1.29 \\
\hline BRK11 & 2.3 & 0.66 & 2.9 & 76.4 & 20 & 3.6 & 1.90 & 0.95 & 1.90 \\
\hline BRK12 & 1.8 & 1.64 & 9.1 & 62.5 & 31.3 & 6.2 & 1.76 & 0.46 & 1.76 \\
\hline BRK13 & 1.01 & 0.62 & 6.1 & 45.2 & 9.6 & 45.2 & 1.21 & 0.81 & 1.21 \\
\hline GZ8 & 2.4 & 0.12 & 0.5 & 21.4 & 64.3 & 14.3 & 1.90 & 1.18 & 0.35 \\
\hline GZ9 & 0.9 & 0.8 & 8.9 & 27 & 56.8 & 16.2 & 1.15 & 1.05 & 0.94 \\
\hline GZ10 & 1.5 & 0.52 & 3.5 & 54.2 & 8.7 & 37.1 & 1.94 & 0.83 & 0.44 \\
\hline GZ12 & 2.9 & $\mathrm{Nd}$ & $\mathrm{Nd}$ & $\mathrm{Nd}$ & $\mathrm{Nd}$ & $\mathrm{Nd}$ & 2.29 & 1.20 & 0.44 \\
\hline GZ13 & 1.02 & $\mathrm{Nd}$ & $\mathrm{Nd}$ & $\mathrm{Nd}$ & $\mathrm{Nd}$ & $\mathrm{Nd}$ & 1.20 & 0.67 & 0.83 \\
\hline HM8 & 0.71 & $\mathrm{Nd}$ & $\mathrm{Nd}$ & $\mathrm{Nd}$ & $\mathrm{Nd}$ & $\mathrm{Nd}$ & 2.91 & 1.25 & 0.29 \\
\hline HM14 & 0.87 & $\mathrm{Nd}$ & $\mathrm{Nd}$ & $\mathrm{Nd}$ & $\mathrm{Nd}$ & $\mathrm{Nd}$ & 0.47 & 0.73 & 0.22 \\
\hline HM15 & 0.92 & 1.43 & 15.5 & 15 & 20 & 65 & 1.64 & 0.56 & 0.23 \\
\hline HM20 & 0.56 & 1.07 & 19.1 & 17 & 24 & 59 & 1.15 & 0.88 & 0.38 \\
\hline HM30 & 1.2 & 1.86 & 15.5 & 13 & 21 & 66 & 1.09 & 1.01 & 0.89 \\
\hline
\end{tabular}

$130{ }^{\mathrm{a}}$ Total organic carbon; ${ }^{\mathrm{b}}$ chloroform extractable OM; ${ }^{\mathrm{c}}$ nitrogen, sulfur and oxygen heteroatomic

131 compounds; ${ }^{\mathrm{d}}$ saturated hydrocarbons; ${ }^{\mathrm{e}}$ aromatic hydrocarbons; ${ }^{\mathrm{f}} \mathrm{Pr} / \mathrm{Ph}$ peak height ratio; ${ }^{\mathrm{g}}$

$132 \mathrm{Pr} / n-\mathrm{C}_{17}$ peak height ratio; ${ }^{\mathrm{h}} \mathrm{Ph} / n-\mathrm{C}_{18}$ peak height ratio; ${ }^{\mathrm{i}}$ not determined. 


\begin{tabular}{|c|c|}
\hline $\begin{array}{c}\text { Steranes } \\
\text { GC-MS m/z } 217\end{array}$ & $\begin{array}{c}\text { Terpanes } \\
\text { GC-MS m/z } 191\end{array}$ \\
\hline 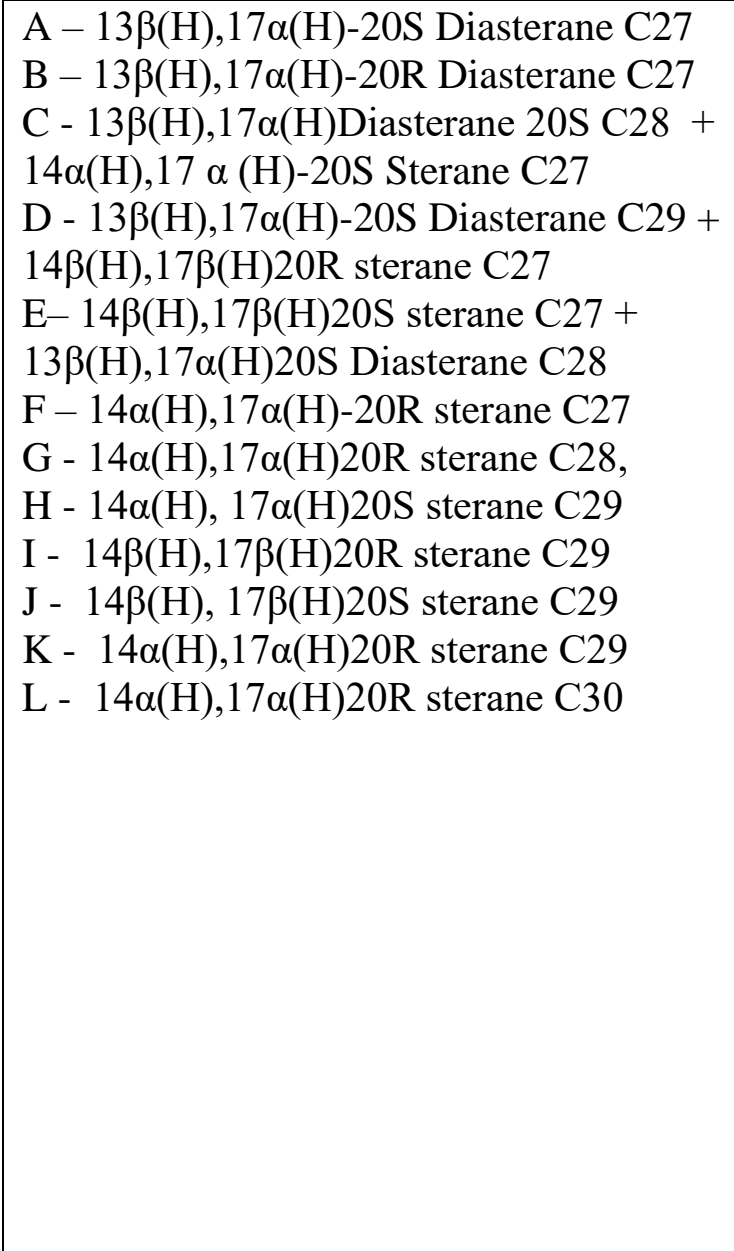 & 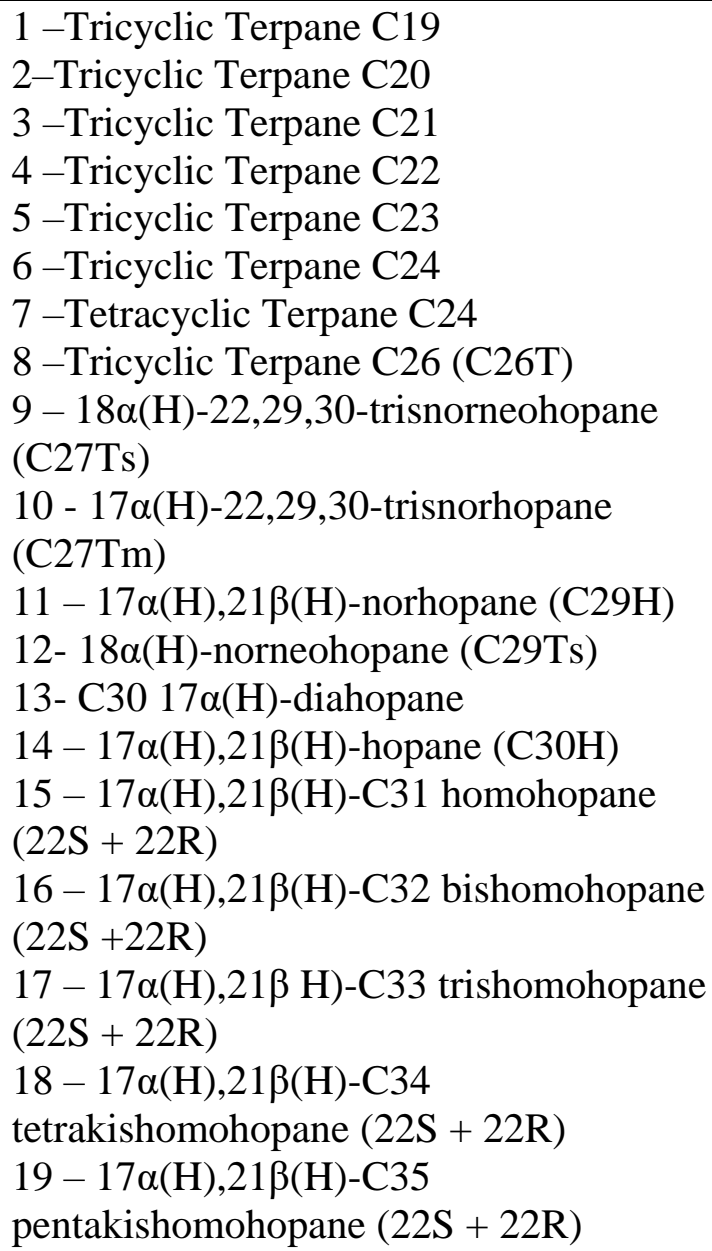 \\
\hline
\end{tabular}




\begin{tabular}{|c|c|c|c|c|c|c|}
\hline \multicolumn{7}{|c|}{ TERPANES m/z 191} \\
\hline Sample & $\mathrm{Ts} / \mathrm{Tm}^{\mathrm{a}}$ & $\begin{array}{c}\mathrm{Ts} / \\
(\mathrm{Ts}+\mathrm{Tm})\end{array}$ & $\begin{array}{l}\mathrm{C} 29 \mathrm{Ts} / \\
\mathrm{C} 29 \mathrm{H}^{\mathrm{c}}\end{array}$ & $\begin{array}{c}\text { Diah/ } \\
{\text { C } 29 H^{d}}^{\text {d }}\end{array}$ & $\mathrm{DI}^{\mathrm{e}}$ & $\begin{array}{l}\mathrm{C} 30 \mathrm{H} / \\
\mathrm{C} 29 \mathrm{H}^{\mathrm{f}}\end{array}$ \\
\hline HM3 & 0.77 & 0.43 & 0.35 & 0.47 & 0.30 & 1.07 \\
\hline HM22 & 2.83 & 0.74 & 1.04 & 1.46 & 0.53 & 1.29 \\
\hline HM26 & 1.63 & 0.62 & 0.84 & 1.30 & 0.50 & 1.30 \\
\hline HM30 & 3.39 & 0.77 & 1.08 & 1.20 & 0.44 & 1.53 \\
\hline BRK12 & 1.85 & 0.65 & 1.93 & 1.19 & 0.25 & 3.63 \\
\hline GZ10 & 1.11 & 0.53 & 0.82 & 0.88 & 0.32 & 1.85 \\
\hline \multicolumn{7}{|c|}{ STERANES m/z 217} \\
\hline Sample & $\begin{array}{c}29 \alpha \mathrm{S} / \\
29 \alpha(\mathrm{S}+\mathrm{R})^{\mathrm{g}} \\
\end{array}$ & \multicolumn{2}{|c|}{$\begin{array}{c}29 \beta \mathrm{S} / \\
29 \beta(\mathrm{S}+\mathrm{R})^{\mathrm{h}}\end{array}$} & \multicolumn{2}{|c|}{$\begin{array}{c}29 \beta(\mathrm{S}+\mathrm{R}) / \\
9 \beta(\mathrm{S}+\mathrm{R})+29 \alpha(\mathrm{S}+\mathrm{R})]^{\mathrm{i}}\end{array}$} & $\begin{array}{c}27 \mathrm{DS} / \\
27 \mathrm{D}(\mathrm{S}+\mathrm{R})^{\mathrm{j}} \\
\end{array}$ \\
\hline HM3 & 0.47 & \multicolumn{2}{|l|}{0.44} & \multicolumn{2}{|l|}{0.45} & 0.68 \\
\hline HM22 & 0.50 & \multicolumn{2}{|l|}{0.55} & \multicolumn{2}{|l|}{0.55} & 0.64 \\
\hline HM26 & 0.45 & \multicolumn{2}{|l|}{0.50} & \multicolumn{2}{|l|}{0.57} & 0.63 \\
\hline HM30 & 0.47 & \multicolumn{2}{|l|}{0.49} & \multicolumn{2}{|l|}{0.60} & 0.62 \\
\hline BRK12 & 0.48 & \multicolumn{2}{|l|}{0.45} & \multicolumn{2}{|l|}{0.62} & 0.59 \\
\hline GZ10 & 0.45 & \multicolumn{2}{|l|}{0.45} & \multicolumn{2}{|l|}{0.62} & 0.59 \\
\hline
\end{tabular}

${ }^{\mathrm{a}}$ Ts/Tm: $18 \alpha(\mathrm{H})-22,29,30$-trisnorneohopane (C27Ts)/ 17 $\alpha(\mathrm{H})-22,29,30$-trisnorhopane (C27Tm)

b Ts/Ts+Tm: 18 $\alpha(\mathrm{H})-22,29,30$-trisnorneohopane (C27Ts)/ [18 $\alpha(\mathrm{H})-22,29,30-$ trisnorneohopane $(\mathrm{C} 27 \mathrm{Ts})+17 \alpha(\mathrm{H})-22,29,30$-trisnorhopane $(\mathrm{C} 27 \mathrm{Tm})]$

${ }^{\mathrm{c}} \mathrm{C} 29 \mathrm{Ts} / \mathrm{C} 29 \mathrm{H}: 18 \alpha(\mathrm{H})$ norneohopane $(\mathrm{C} 29 \mathrm{Ts} 17 \alpha(\mathrm{H}), 21 \beta(\mathrm{H})$-norhopane $(\mathrm{C} 29 \mathrm{H})$

${ }^{\mathrm{d}}$ Diah/C29H: C30 17 $\alpha(\mathrm{H})$-diahopane/ 17 $\alpha(\mathrm{H}), 21 \beta(\mathrm{H})$-norhopane $(\mathrm{C} 29 \mathrm{H})$

${ }^{e}$ DI: Diahopane Index=C30 17 $\alpha(\mathrm{H})$-diahopane/ [C30 17 $\alpha(\mathrm{H})$-diahopane+ $17 \alpha(\mathrm{H}), 21 \beta(\mathrm{H})$ hopane $(\mathrm{C} 30 \mathrm{H})]$

${ }^{\mathrm{f}} \mathrm{C} 30 \mathrm{H} / \mathrm{C} 29 \mathrm{H}=17 \alpha(\mathrm{H}), 21 \beta(\mathrm{H})$-hopane $(\mathrm{C} 30 \mathrm{H}) / 17 \alpha(\mathrm{H}), 21 \beta(\mathrm{H})$-norhopane $(\mathrm{C} 29 \mathrm{H})$

${ }^{\mathrm{g}} 29 \alpha \mathrm{S} / 29 \alpha(\mathrm{S}+\mathrm{R})=14 \alpha(\mathrm{H}), 17 \alpha(\mathrm{H}) 20 \mathrm{~S}$ sterane $\mathrm{C} 29 /[14 \alpha(\mathrm{H}), 17 \alpha(\mathrm{H}) 20 \mathrm{~S}$ sterane $\mathrm{C} 29+14 \alpha(\mathrm{H})$, $17 \alpha(\mathrm{H}) 20 \mathrm{R}$ sterane $\mathrm{C} 29]$

h $29 \beta \mathrm{S} / 29 \beta(\mathrm{S}+\mathrm{R})=14 \beta(\mathrm{H}), 17 \beta(\mathrm{H}) 20 \mathrm{~S}$ sterane $\mathrm{C} 29 /(14 \beta(\mathrm{H}), 17 \beta(\mathrm{H}) 20(\mathrm{~S}+\mathrm{R})$ sterane C29).

i $29 \beta(\mathrm{S}+\mathrm{R}) /[29 \beta(\mathrm{S}+\mathrm{R})+29 \alpha(\mathrm{S}+\mathrm{R})]=14 \beta(\mathrm{H}), 17 \beta(\mathrm{H}) 20(\mathrm{~S}+\mathrm{R})$ sterane $\mathrm{C} 29 /(14 \beta(\mathrm{H})$,

$17 \beta(\mathrm{H}) 20(\mathrm{~S}+\mathrm{R})$ sterane $\mathrm{C} 29+14 \alpha(\mathrm{H}), 17 \alpha(\mathrm{H}) 20(\mathrm{~S}+\mathrm{R})$ sterane $\mathrm{C} 29)]$

j 27DS/27D(S+R)=13 $\square(\mathrm{H}), 17 \alpha(\mathrm{H})-20 \mathrm{SDiasterane} \mathrm{C} 27 /[13 \square(\mathrm{H}), 17 \alpha(\mathrm{H})-20(\mathrm{~S}+\mathrm{R})$ Diasterane C27] 